\title{
LAS TÉCNICAS NARRATIVAS DE LA NOVELA ESPAÑOLA DE LA POSGUERRA, CON LA ATENCIÓN ESPECIAL A LA NOVELA DE LOS AÑOS SESENTA ${ }^{1}$
}

\begin{abstract}
Abri la jaula y dejé volar al pájaro. Hay que respetar su vuelo, no intentar pillarlo. El autor y su correlativo el lector saben muy bien que, contrariamente al refrán, valen menos cien pájaros en mano que el que, para delicia y tortura nuestra, leve, alígero, esbelto, sigue y seguirá volando.
\end{abstract}

Juan Goytisolo

\section{Introducción}

En los años sesenta de la posguerra española aparecen tres novelas que pueden ser consideradas como novelas de ruptura: Tiempo de silencio (1962) de Luis Martin-Santos, Señas de identidad (1966) de Juan Goytisolo y Cinco horas con Mario (1966) de Miguel Delibes.

Las tres obras son ejemplo de un nuevo paradigma en la narrativa española de posguerra que la historia y la crítica literaria suelen denominar realismo dialéctico. Este tipo de realismo introduce muchas novedades formales queriendo liberarse del realismo social o realismo objetivo, vigente en la literatura española de posguerra aproximadamente hasta los comienzos de los años sesenta. A pesar de muchas novedades formales, entre ellas la más importante es la introducción de nuevas técnicas narrativas, las tres novelas guardan, sin embargo, muchas conexiones con la corriente precedente. Los autores mencionados introducen las novedades literarias sobre todo por dar una respuesta artísticamente adecuada a las condiciones agobiantes de la época franquista.

Lo que tienen en común las tres novelas, en breve, es búsqueda, inquietud, cambio, movimiento, destrucción de mitos, transformación social, ansia de renovación, desesperanza, frustración, tradición y ruptura. Las tres novelas andan por nuevos caminos en busca de nuevas metas y reflejan una perspectiva distinta ante una realidad nacional cambiante. Por esta razón las tres prestan gran cuidado al estilo y a la experimentación con el lenguaje que se manifiesta también en el uso de otros idiomas: inglés, francés, catalán, y esto no solamente en citas breves sino en pasajes completos. Pero cada una es una respuesta diferente a

\footnotetext{
1 A continuación sigue el resumen de la tesis doctoral con el titulo Pripovedne tehike v povojnem španskem romanu s posebnim poudarkom na šestdeseta leta dvajsetega stoletja (Las técnicas narrativas de la novela española de la posguerra, con la atención especial a la novela de los años sesenta), realizada por la autora del presente artículo para obtener el grado de doctor en letras. La tesis fue dirigida por la profesora Mirjana Polić Bobić de la Universidad de Zagreb (Croacia) y defendida el 27 de mayo de 1996 en la Universidad de Ljubljana (Eslovenia).
} 
los problemas de España y del mundo de aquella época. Todas son obras representativas de la novelística española en la década de los sesenta y pueden definirse como obras del realismo diálectico o novelas de ruptura.

\section{El contexto socio-cultural}

Durante la Guerra Civil y una vez finalizada ésta, un considerable grupo de intelectuales, defensores de la República, abandona España con destino a Europa, Hispanoamérica o los EE.UU. Gonzalo Torrente Ballester señaló ${ }^{2}$ que los intelectuales exiliados representaban aproximadamente el noventa por ciento de la inteligencia española. Entre dichos exiliados figuraban novelistas tan importantes como Francisco Ayala, Ramón J. Sender, Max Aub y otros más. Esta generación perdida en condiciones normales hubiera continuado la tradición novelística de la preguerra, pero no fue así. Sus obras no se conocieron en España hasta fechas muy posteriores, debido a las prohibiciones de impresión y edición y al silencio impuesto sobre éstas por los escritores y críticos españoles que permanecieron en España después de la guerra. Algunos autores importantes también murieron: Unamuno, ValleInclán, Maeztu, García Lorca, Antonio Machado, muy pronto también Miguel Hernández. En la posguerra inmediata quedaba un inmenso vacío. Como ha escrito José Luis Abellán: «la situación cultural de España en el período inmediato a la Guerra Civil, y como consecuencia de la misma, fue la de un auténtico páramo intelectual» ${ }^{3}$. Sin embargo hubo intelectuales que permanecieron en España y otros que regresaron en los primeros momentos de la posguerra: Azorín, Benavente, Baroja, Menéndez Pidal, Gregorio Marañón, Eugenio D'Ors, Manuel Machado, Vicente Aleixandre, Dámaso Alonso, etc; más tarde —en 1945 - volvería Ortega y Gasset, depsués Ramón Pérez de Ayala. La mayor parte de ellos y otros más jóvenes vivían en un cierto exilio interior. Pocos concordaban voluntariamente con las nuevas directrices de la política cultural oficial, y en esas condiciones no era fácil trabajar. El corte de la guerra alejó para siempre no sólo a artistas que tenían aún mucho que decir y hacer, sino también a corrientes culturales enteras que se perdieron en el exilio y nunca pudieron ser recuperadas.

La cultura oficial rompió toda comunicación con la cultura europea de raíz liberal. Su obsesión era la absoluta uniformidad ideológica, donde la libertad intelectual poseía muy pocas posibilidades de acción. La consecuencia de esta situación fue la existencia de la censura muy rigurosa. La Ley de Prensa promulgada en abril de 1938 imponía la censura previa de todo lo que se quería imprimir y se mantuvo hasta la liberalización que supuso la Ley de Prensa e Imprenta de Fraga en 1966.

La censura operaba en un doble sentido: de un lado prohibía la difusión de determinadas obras y, de otro, condicionaba la autocensura del artista. En los años cuarenta la censura vi-

2 En la revista Tajo, Madrid, 3 de agosto de 1940.

3 Abellán, José Luis: La cultura en España. Ensayo para un diagnóstico, Madrid, Cuadernos para el Diálogo, 1971, p. 9. 
gila los peligros para la fe y las buenas costumbres. Es una censura de «inspiración eclesiástica», según Dionisio Ridruejo. ${ }^{4}$

La censura constante sobre los escritores y artistas produjo en ellos cierto tipo de autocensura, aunque también favoreció en el campo literario la aparición de una literatura de alusión, que exigía una lectura entre líneas. Juan Goytisolo piensa que: «Si algún mérito hay que reconocer a la censura es el de haber estimulado la búsqueda de las técnicas necesarias al escritor para burlarla e introducir de contrabando en su obra la ideología o temática prohibidasy. 5

La declaración de Jorge Luis Borges es muy parecida:

«La censura puede ser ventajosa porque obliga a los escritores a decir las cosas de un modo indirecto, es decir, más eficaz. Creo que si el siglo XVIII hubiera permitido una libertad total, el mundo habría perdido la ironía de Voltaire, por ejemplo. De modo que, indirectamente, la censura puede ser beneficiosa para la literatura». ${ }^{6}$

El público de la primera posguerra leía apenas novelas españolas; devoraba, en cambio, largas novelas extranjeras de segundo orden con temas exóticos y biografías de hombres singulares, sobre todo de personajes de la España imperial. La crisis de la novela española, anunciada por Ortega en 1925, continuaba. Además, el público buscaba el olvido y temía que sus novelistas le ofreciesen asuntos de la guerra. De este modo se difunde una narrativa que pretende hacer olvidar la sangrienta realidad de ayer y la dolorosa de la posguerra, fenómeno que también se registra paralelamente en la poesía lírica y en el teatro. A falta de una narrativa nacional, el lector recurre a los novelistas extranjeros, a las largas novelas llenas de sorpresas, de fantasía y problemas pasionales en un escenario misterioso y fantástico. Los más leídos entonces fueron P. Buck, L. Bromfield, W. S. Maugham, Ch. Bronte, D. de Maurier, C. Roberts, S. Swing, M. van der Meerch etc., autores «de no mucha calidad y poco reputados en su país de origen». ${ }^{7}$

¿Qué ocurre con la literatura subjetiva de la preguerra, defendida en las teorías de la "deshumanización del arte" de José Ortega y Gasset? El efecto de la Guerra Civil y de la penosa realidad de la posguerra entre los novelistas fue la toma de conciencia del horror. En tales condiciones la novela experimental, intelectual, lírica o humorística de preguerra no podía satisfacer a los que les había tocado vivir en realidad tan dura. Las corrientes literarias extranjeras son desconocidas por aquel entonces por los novelistas españoles y España permanece al margen de las transformaciones más decisivas en el género novelesco. Entonces

4 Ridruejo, Dionisio: «La vida intelectual española en el primer decenio de la posguerra», Triunfo, no. 507, Madrid, 17 de junio de 1972, p. 71.

5 Goytisolo, Juan: «Los escritores españoles frente al toro de la censura» en El furgón de cola, Barcelona, Seix Barral, 19822, p. 56.

6 Santana, Lázaro: «La vida y la brújula. Conversación con Borges», Insula, núm. 258, Madrid, mayo de 1968, p. 5.

7 Martinez Cachero, José María: La novela española entre 1936 y 1969. Historia de una aventura, Madrid, Castalia, 1973, p. 74. 
la continuidad novelística se buscará en la tradición realista española, especialmente en la novela picaresca, la corriente realista o naturalista del siglo XIX y en el coetáneo Pío Baroja. Éste declaró acerca del porvenir de la novela española:

«No creo que el ambiente actual sea muy propicio para el desarrollo de la novela. El hecho de la guerra [se refiere a la guerra mundial] no da a las sociedades una sensación de vida segura, que yo considero imprescindible; la situación en el mundo es tan fuerte que los españoles se encuentran psicológicamente en el volcán de Europa». ${ }^{8}$

Ya en 1945 Camilo José Cela empieza a renovar de verdad los caminos novelescos con el tremendismo (que él lo entiende como «sanguinaria caricatura de la realidad y no su sangriento retrato que, a las veces, la misma disparatada realidad se encarga de forzarlo a lo monstruoso y deforme») $)^{9}$ y con La familia de Pascual Duarte:

«La invención literaria, en España, está pasando por un evidente buen momento que quizá pudiéramos calificarlo de "inicial". Creo que, con el transcurso del tiempo, este inicial momento llegará a ser definitivo». ${ }^{10}$

En la inmediata posguerra tuvo mucha influencia a la baja calidad de la novela española la crítica destructiva y la influencia negativa del cine. La crítica no puede prosperar allí donde no existe la libertad de prensa. No sólo la censura suprimía lo que consideraba en desacuerdo con las premisas del régimen, sino también el crítico sabía que no debía observar determinadas cosas. ¿Cómo podría criticar negativamente una mala novela de algún escritor favorecido por la política? $\mathrm{O}$, ¿cómo podría elogiar a un exiliado o a alguien de ideas en desacuerdo con la política oficial? La crítica fue floja y tímida, y en vez de favorecer la creación exigente, repartía aplausos falsos e infructuosos.

Por otro lado, el cine norteamericano influyó también negativamente a la renovación de la novela española. Algunos de los novelistas extranjeros que entonces se leían en España deben su éxito al cine. Daphne du Maurier, Louis Bromfield o Sommerset Maugham acaso hubieran permanecido incógnitos si el público no hubiese conocido las películas hechas a base de sus novelas: Rebeca, Vinieron las lluvias, El filo de la navaja. La gente compraba esas novelas para volver a disfrutar de las películas.

Por las razones literarias y también extraliterarias difícilmente podría surgir en la España de la inmediata posguerra una novela que no fuese de la tradición realista española. El aislamiento cultural mantuvo a la novelística española al margen de la renovación novelesca que

\footnotetext{
8 Anónimo: «Baroja declara que no es tiempo de novelas», El Español, núm. 10, Madrid, 2 de enero de 1943, p. 6.

9 Cela, Camilo José: «Dos tendencias de la nueva literatura española», Papeles de Son Armadans, núm. LXXIX, Madrid - Palma de Mallorca, octubre de 1962, p. 10.

${ }^{10}$ Cela, Camilo José: «Encuesta sobre la invención literaria», La Estafeta Literaria, núm. 28, Madrid, 10 de junio de 1945 , p. 15.
} 
en Europa y América llevan a cabo los grandes maestros de la narrativa mundial como $\mathrm{M}$. Proust, A. Gide, F. Kafka, T. Mann, J. Joyce, A. Huxley, W. Woolf, W. Faulkner y otros más.

En los años cincuenta paralelamente a la tímida apertura política, se producía también una política del deshielo moderado en el mundo de la cultura, a pesar de las limitaciones impuestas por el régimen. A pesar de todo no cabe la menor duda de que se estaba preparando un auténtico renacimiento de la cultura española, sumida en una profunda somnolencia desde hacía ya más de diez años. Los primeros síntomas de este renacimiento se dieron en el terreno de la creación plástica. Los grupos de artistas que se formaron en Barcelona primero (Dau al Set) y en Madrid después (El Paso) cultivaban un tipo de arte abstracto colocando a la pintura española en la vanguardia misma de la pintura europea. Con el estreno de la obra Historia de una escalera de Antonio Buero-Vallejo en 1949 se planteaban en el teatro, por primera vez desde la guerra, abiertamente los problemas sociales del pueblo español. También otros jóvenes dramaturgos proclamaban la necesidad de un teatro de agitación social que sirviera para la renovación de la sociedad española. En el terreno de la poesía la aparición de los poetas como Gabriel Celaya y Blas de Otero suponía también una ruptura con la poesía anterior y una nueva concepción de la figura misma del poeta, antes encerrado un su torre de marfil, ahora quiere participar en la reivindicación social.

Pero quizá fuera en el terreno de la narrativa donde se estaban produciendo los cambios importantes. En 1950 publicaba Camilo José Cela La Colmena, que, al introducir el personaje colectivo, el uso de la técnica cinematográfica en la novela y el empleo del lenguaje coloquial basado en el argot madrileño, renovaba los principios mismos de la narrativa española. Pero la obra de Cela no es un fenómeno aislado. En la narrativa de aquella década se estaba poniendo en marcha el llamado realismo social o neorrealismo que dio muchos frutos importantes. Santos Sanz Villanueva ha reducido las razones, por las cuales asistimos por esos años a un cambio en la narrativa, a las siguientes más importantes:

- salida de España del aislamiento internacional,

- mayor libertad y flexibilidad de la censura,

- descubrimiento de la novela extranjera,

- progresiva temática social,

- política editorial más abierta,

- premios literarios. ${ }^{11}$

Los novelistas que practicaban el realismo social u objetivo tenían algunos rasgos en común. En primer lugar, han nacido pocos años antes de la guerra y no participaron en ella como combatientes sino sufrieron hambres, desplazamientos, bombardeos como víctimas inocentes. El segundo es el de haber crecido y vivido el período de su formación juvenil en el aislamiento del mundo exterior al que España estuvo sometida durante toda la década de los años cuarenta, por la Segunda Guerra Mundial y por la resolución de las Naciones Unidas de retirada de embajadores, etapa que duró de 1946 hasta 1950. A causa de un futuro

11 Sanz Villanueva, Santos: Tendencias de la novela española actual, Madrid, Edicusa, 1972, pp. 43-44. 
político y económico incierto, los jóvenes novelistas casi obesivamente intentan estudiar, analizar y describir la situación actual de su país, su estructura social, las consecuencias de la Guerra Civil, etc. Se adhieren, consciente o inconscientemente, a una literatura testimonial, comprometida, realista. Es aceptado por la crítica que casi todas las novelas españolas de aquella época de la posguerra elaboran temas sociales en todas sus implicaciones de conflicto o de injusticia, con intención crítica o un deseo de denuncia.

Los autores de la década del 50 pertenecen a la llamada generación del medio siglo, denominada así por José María Castellet. Frente a la cerrada situación de la generación de escritores de la guerra, la generación del medio siglo se abre ansiosamente al extranjero en busca de referencias y comparaciones, lo cual les hace volverse críticamente al ámbito nacional. Algunos críticos la comparan con la generación del 98 . Si ésta también tenía como tema central el futuro de España, pero desde el enfoque que buscaba sentimentalmente los valores eternos de España, la generación del medio siglo analiza la situación concreta sin referencias nostálgicas, pretende ser el testigo de la realidad y, a través de la narrativa, sustituir deficiencias informativas y de juicio. Dice Pablo Gil Casado:

«Todos los escritores españoles sentíamos necesidad de responder al apetito informativo del público dando una visión de la realidad que escamoteaba la prensa. En cierto modo, creo que el valor testimonial de la literatura española de estos años reside en estor. ${ }^{12}$

Los autores del medio siglo, inspirados por la problemática social de las clases explotadas, no escriben para el pueblo que, por su situación cultural, no tiene acceso a tales lecturas, sino que se dirigen a un público minoritario. De ahí proviene cierta paradoja que constituyen estos escritores al pretender ser exponentes de una realidad social concreta y superar al mismo tiempo lo anecdótico para crear una obra permanente a la vez que testimonial.

Entonces, en los años cincuenta los novelistas cultivan la novela social de carácter testimonial y crítico, de técnica generalmente objetivista, rechazan la literatura como fin y, en consecuencia, ajena a todo experimento formal excesivo, porque en esas circunstancias interesa más el qué que el cómo de las novelas.

Nuevas circunstancias de la década del 60 han transformado la vida económica y social del país. Al período de aislamiento interior y exterior, sucede una nueva fase determinada por la guerra fría que incorpora otra vez a España a la corriente internacional, situándola en la esfera de influencia norteamericana. Se trata de intereses mutuos, pues los Estados Unidos buscan bases militares en la zona del Mediterráneo, mientras que España, por su parte, recibe ayuda económica estadounidense. Abiertas ya sus fronteras, una ola turística invade el pais mientras se inicia, por otro lado, el éxodo de obreros y campesinos españoles a los países de Europa en busca de trabajo. Ese conjunto de hechos obligan al régimen franquista a

12 Gil Casado, Pablo: La novela social española (1920-197I), Barcelona, Seix Barral, $1973^{2}$. 
un cambio de rumbo económico, político y social. Y en 1960, al abrir los ojos, los novelistas se dan cuenta de que la situación que describen en sus obras ya no existe en España.

Un mayor bienestar material ha hecho posible que las masas comiencen a disfrutar de los bienes de consumo, lo que ha traído consigo la mercanitlización de la vida y el abandono de valores propios de una sociedad subdesarrollada. Como piensa Fernando Morán en su artículo Sobre el semidesarrollo ${ }^{13}$, el problema central es que el mero crecimiento económico no produce cambios culturales correspondientes, que el cambio económico es anterior al social y los dos al ideológico. La posición intelectual es equívoca: ni es un intelectual institucionalizado, encuadrado en las estructuras académicas, ni su actividad significa negación vanguardista del sistema; en breve, la cultura en aquel entonces no tiene una función pública reconocida por el estado. El intelectual está condenado a la semiparticipación y a una influencia relativa y esporádica.

El semidesarrollo es una situación en que España se encuentra en los años sesenta. Juan Goytisolo la describe en su ensayo Examen de conciencia, publicado en el libro El furgón de cola:

«En restaurantes, hoteles, comercios, oficinas, despachos públicos, este desentreno social se traduce en improvisación, ineficacias, torpeza, confusionismo. Sorprendido por el maná caído del cielo, el español se enfrenta a la nueva situación sin una preparación moral y social adecuadas. En los últimos cinco años el país ha perdido la mayor parte de las características de la sociedad subdesarrollada sin alcanzar por eso las ventajas materiales y técnicas de las sociedades más ricas.

[...]

En lo exterior las apariencias no han cambiado y los atributos del "alma española" fascinan y seguirán fascinando a nuestros visitantes: los toros, el cante flamenco, el piropo, el donjuanismo, etc. Pero desengañémonos. Estos atributos pierden y perderán cada vez más su verdad original. Obligados a mantenerlos y exhibirlos por las necesidades del turismo, los españoles comienzan a dudar interiormente de ellos». ${ }^{14}$

A todo lo mencionado hay que añadir el propósito del régimen de ofrecer un rostro democrático, liberalizado y abierto a los visitantes extranjeros, así como una cierta relajación del aparato de la censura. «Obligado a aceptar el fait accompli, el Régimen procura sacar, como es natural, el mayor provecho a una situación que no había previsto y que, en definitiva, escapa de sus manos». ${ }^{15} \mathrm{El}$ artista español se siente alejado del compromiso testimonial y vuelve a comprender que el arte tiene sus propias sutiles normas. Las grandes obras de todos

\footnotetext{
${ }^{13}$ Morán, Fernando: «Sobre el semidesarrollo», separata del Boletin informativo de ciencia política, núm. 4, Madrid, junio de 1970, pp. 1-14.

14 Goytisolo, Juan: op. cit., $1982^{2}$, pp. 254-255.

15 Goytisolo, Juan: Ibid., p. 254.
} 
los tiempos han dejado testimonio de su época y han trascendido el mensaje artístico, sin que el autor se haya propuesto deliberadamente servir a otros intereses que no fueran los de su arte. Las ideas que un escritor tiene se transparentan en su obra y llegan a imponerse tanto más cuanto menos evidente sea el propósito de convencer.

La novelística española ha entrado nuevamente por los caminos del arte verdadero y ya no por los de la historia social. La novela se aprovecha ahora de las innovaciones formales de la novela europea y americana, en todas partes dominada por un espíritu de experimentación y cambio. La mejor novelística española de la década de los sesenta abandona su anterior sujeción al realismo y se enriquece con toda clase de experimentos formales y expresivos, un espíritu abierto a los nuevos modos de narrar, una concepción dinámica del arte de novelar, una mayor riqueza de puntos de vista y formas de expresión. La aceptación de una posición intelectual ante la novela ha dado entrada a la metafísica, al deseo de trascender, de universalizarse, de elevarse sobre la anécdota, sin abandonarla, pero haciéndola más honda y más relevante.

Nuevas ideas demandan nuevas formas de expresión. Los novelistas de aquella época han dado enorme importancia al tratamiento del lenguaje, a la realización lingüística. Hace mucho tiempo que el lenguaje había tenido un rango tan esencial y determinante. El lenguaje que había servido hasta entonces para ocultar o mentir, debe ser destruido y purificado por el creador literario que ha de ser no sólo un verdadero cultor de la lengua sino un renovador de su instrumento de expresión. El lenguaje se vuelve críticamente contra sí mismo para desenmascarar sus convencionalismos y romper los viejos criterios falsos y formalistas. Si tras una retórica purista se esconde todo un mundo de falsedades, el artista tiene que inventarse una nueva palabra para alzarse contra eso. Luis Martín-Santos, Juan Goytisolo y Miguel Delibes revisan de un modo analítico todos los estratos del español: la retórica oficial, la académica, la periodística, la jerga de las chabolas, de la policía, de los estudiantes, del hombre de la calle.

El esfuerzo inicial por la renovación lingüística partió de Hispanoamérica. Alejados del yugo de la Academia y expuestos a una mayor influencia de elementos naturales de renovación (lo indio, lo negro), los escritores hispanoamericanos han basado sus obras en unas renovaciones del lenguaje, en el análisis dialéctico de su expresión literaria; han enriquecido el vocabulario y la sintaxis del idioma español en un movimiento renovador que permitiera extraerle a la lengua todas sus posibilidades creadoras.

En suma, después de la Guerra Civil la actitud de los más destacados narradores debe calificarse de realista, entendiendo por realismo la atención primordial a la realidad presente y concreta. Ser realista significa tomar esa realidad como fin de la obra de arte, y no como medio para llegar a ésta: sentirla, comprenderla, interpretarla con exactitud y expresarla lo más verídicamente posible.

En la España de posguerra, más que en otros países, es importante este valor testimonial de la novela. No es el único, pero es importante porque en España la prensa, que sería el 
medio normal de testimoniar la realidad, a lo largo de muchos años no suele dar una imagen completa de la realidad española. De eso habla Juan Goytisolo en su entrevista con Emir Rodríguez Monegal:

«En España la prensa es más bien una cortina de humo. Durante muchos años ocurrían una serie de cosas importantísimas en el país que la prensa no mencionaba siquiera: era una prensa para ocultar, no para revelar. Todos los escritores españoles sentíamos una necesidad de responder al apetito informativo del público dando una visión de la realidad que escamoteaba la prensa. En cierto modo creo que el valor testimonial de la literatura española de estos años reside en esto. Este es el origen y el historiador futuro tendrá que recurrir al análisis de la narrativa española si quiere colmar una serie de vacios y de lagunas provocados por la carencia de una prensa de información veraz y objetiva». 16

Debido a las duras condiciones de vida y trabajo (represión, censura, miseria material y moral) los escritores españoles fueron forzados a recurrir al realismo que les fue impuesto como corriente prácticamente obligatoria a causa de las circunstancias extraliterarias.

Sólo en los años sesenta cuando empieza la apertura económica, política y cultural, los artistas pueden ir abandonando las técnicas realistas para acercarse paulatinamente a los movimientos experimentalistas que en otras literaturas ya estaban en su auge, pero no abandonando los temas sociales de la época anterior. En este sentido se pueden considerar las novelas Tiempo de silencio de Luis Martín-Santos, Señas de identidad de Juan Goytisolo y Cinco horas con Mario de Miguel Delibes como novelas de ruptura.

\section{Censura y profesión literaria}

«"Los escritores españoles - me decía en una oocasión un colega parisiense - tienen una enorme ventaja sobre nosotros. La existencia de la censura previa, la prensa controlada y dirigida, la rigidez e inflexibilidad de la sociedad en que viven son factores estimulantes para un espíritu libre y audaz. La acumulación de dificultades y obstáculos desanima a los débiles y a los advenedizos; es una escuela de disciplina singularmente provechosa. Enfrentada a las barreras alzadas por el conservadurismo y la intolerancia su vocación artísitca sale fortalecida." [...] Quien así se expresaba era sincero sin duda, pero yo recordaba algunos discursos patronales que había oído durante mi niñez y me decía para mí: "El problema tiene fácil arreglo, señor mío. Si tanto nos envidia la suerte, ¿por qué no se viene a trabajar usted a nuestro país?» ${ }^{17}$

\footnotetext{
16 Rodríguez Monegal, Emir: El arte de narrar, Caracas, Venezuela, Monte Avila Editores, $1977^{2}$, p. 180.

17 Goytisolo, Juan: op. cit., $1982^{2}$, p. 41.
} 
La censura es el medio represivo de que disponen los gobiernos débiles de todo el mundo para despersonalizar a la población y convertirla en una masa uniforme, produciendo en ella una parálisis política, social y cultural. Una de las características primordiales del funcionamiento del aparato censor es la arbitrariedad con que sus ejecutores deciden qué puede o no publicarse. La censura sirve para impedir sistemáticamente la propagación de determinadas experiencias históricas, modos de vida, costumbres o ideologías.

La represión cultural fue la opción histórica que el bloque vencedor había adoptado después de la Guerra Civil y que no admitía ningún tipo de crítica ni niguna manifestación de ideología democrática. Finalizada la Guerra, las dos ideas clave del régimen establecido serán: orden interior y supervivencia a cualquier precio. El falanguismo como movimiento ideológico queda reducido a ser un componente más del Nuevo Estado y tiene que seguir luchando por su "revolución pendiente", incluso después de la victoria militar de 1939. El régimen se quedó sin ideología definida. Por eso, quizás, tuvo que luchar contra todas. Conscientes de esta debilidad intelectual, los creadores del nuevo estado acogieron, al parecer, con mayor entusiasmo el «muera la inteligencia» del general falangista Millán Astray que la idea de construir un sistema cultural consistente. Muchos de los intelectuales, que masivamente salieron hacia el exilio, dejaron en la conciencia histórica de la sociedad española sus planteamientos culturales liberales. Pero la dureza de la represión hizo prácticamente imposible la expresión y el debate creador sobre aquellas ideas.

En el contexto del vacío cultural e histórico la censura pone como puntos esenciales de su código la intangibilidad de jefes e instituciones y la defensa del orden. Predominaba la idea de destrucción de todo lo que no se ajustara a las premisas del nuevo estado. En el campo literario, los funcionarios de censura dedicaban el tiempo a labores de crítica literaria, a demostrar la inconsistencia de la trama, la falta de profundidad psicológica de los personajes o la impresión vaga de un poema. Todo estaba bajo control. La censura de libros se ciñó desde sus comienzos a un sencillo esquema inquisitorio:

- ¿Ataca al dogma?;

- ¿ataca a la moral?;

- ¿ataca a la Iglesia o a sus ministros?;

- ¿ataca al Régimen y sus intituciones?;

- ¿ataca a las personas que colaboran o han colaborado con el Régimen?;

- los pasajes censurables, ¿califican el contenido total de la obra?;

- informe y otras observaciones. ${ }^{18}$

Temas especialmente tabús son, en la etapa de la primera posguerra, la Guerra Civil (a la que tiene que llamarse "Glorioso Alzamiento Nacional"), las ideas políticas contrarias al régimen, el catolicismo tratado poco ortodoxamente, la moral $\mathrm{y}$, dentro de este campo, la sexualidad, el suicidio y la blasfemia.

18 Abellán, Manuel L.: Censura y creación literaria en España (1939-1976), Barcelona, Península Ediciones, 1980 , p. 19. 
En los años sesenta se asistía a un proceso de liberalización económica tratando de abrir la economía al neocapitalismo competitivo. Había que acomodar los viejos mecanismos de control ideológico a los nuevos métodos de organización económica. El equipo que se incorporó al Ministerio de Informaciones y Turismo con Fraga Iribarne a la cabeza comprendió que tenían que ordenar la transición, despertar los fantasmas como liberalismo, pensamiento democrático, enseñar Europa a los españoles y ofrecer a Europa y al mundo la imagen de una España que empezaba a quitarse el manto de la leyenda negra.

En la práctica, la Ley de Prensa e Imprenta (1966) no ha podido resolver la contradicción que suponía la necesidad de libertad de expresión con las razones de un poder que todo lo había codificado en función de la fuerza. La necesidad de libre difusión de las ideas era deseada por las nuevas burguesías urbanas, por los nuevos profesionales surgidos de las universidades cada vez más críticas y por nuevas generaciones que no habían sido traumatizadas directamente por la Guerra Civil. La Ley de Prensa representaba la superación del dirigismo cultural fanáticamente practicado durante las primeras décadas de la posguerra. Con ella se abría la "primavera de Fraga" que, sin embargo, estaba medida ("apertura vigilada" se la suele llamar) para no violar nada que pudiera ser considerado parte de la legislativa: respeto a la verdad y a la moral, sumisión a las leyes fundamentales del régimen, las exigencias de la defensa nacional, de la seguridad del Estado y del mantenimiento del orden público interior y la paz exterior, el debido respeto a las instituciones y a las personas en la crítica de la acción política y administrativa, la independencia de los tribunales y el respeto de la intimidad y del honor personal y familiar. Entonces, muchos de los artículos de la Ley de Prensa estaban redactados con una vaguedad tan absoluta que los que habian de aplicarlos siempre podían encontrar justificación para usar el lápiz rojo.

La Ley de Prensa e Imprenta suponía, entonces, la desaparición teórica del sistema de censura de libros, pero la consulta previa dejaba abierta la puerta a su existencia práctica, porque el autor, editor o importador tenía que someter el original o la obra importada al examen de la administración que debía informar positiva o negativamente. La censura, en diez años de la Ley de Prensa, ha ido progresivamente retirando algunos de los temas prohibidos, pero jamás han dejado de existir cuestiones tabús. Paulatinamente el organismo censorial relajaba su sitema de opresión a causa de los funcionarios más liberales y abiertos para las ideas democráticas. ${ }^{19}$ Con la muerte de Franco desaparece de hecho el sistema político estructurado sobre su "irrepetible" personalidad y puede empezar el proceso hacia la total desaparación de la censura de libros, lo que no ocurrirá hasta 1977.

\footnotetext{
${ }^{19}$ Según Cruz Hernández, Miguel: «Del deterioro al desmantelimiento: los últimos años de la censura de libros», Diálogos Hispánicos de Amsterdam, núm. 5, Amsterdam, Rodopi Editores, 1987, pp. 41-56, en 1961 con una edición anual de poco más de 4.000 titulos la supresión se acercaba a los 300 títulos, lo que puede calcularse en $9,5 \%$; en 1966 la supresión ha disminuido al 4,3\% y en 1973 al $2,8 \%$.
} 


\section{El realismo narrativo en la posguerra española}

Según Gonzalo Sobejano en el nuevo realismo ${ }^{20}$ de la posguerra pueden señalarse tres direcciones:

- hacia la existencia del hombre contemporáneo en aquellas situaciones extremas que ponen a prueba la condición humana (novela existencial);

- hacia el vivir de la colectividad en estados y conflictos que revelan la presencia de una crisis y la urgencia de su solución (novela social);

- hacia el conocimiento de la persona mediante la exploración de la estructura de su conciencia de todo su contexto social (novela estructural o dialéctica). ${ }^{21}$

La primera dirección predomina en los narradores que se dieron a conocer en los años cuarenta que fueron años de infradesarrollo. La segunda dirección predomina en los narradores que se dieron a conocer en los años cincuenta, años de desarrollo incipiente. El crítico José Maria Castellet los llama la Generación del medio siglo que empezó a publicar a partir de 1950. Esta generación, por su alejamiento cronológico de la guerra, en la cual no ha participado y de la que sólo conoce sus consecuencias, tiene más objetividad para un análisis moral del conflicto. Para ellos la novela se convierte en un instrumento de denuncia de las estructuras socio-económicas españolas. Por eso esta generación de escritores se abre a las novedades y a las corrientes literarias que circulan más allá de las fronteras nacionales, lo cual los hace feroces críticos del ámbito nacional. La tercera dirección predomina en los narradores que se han dado a conocer en los años sesenta, años de expansión económica y cierta liberalización ideológica y cultural. La novela estructural o dialéctica trata de identificar el contexto social desde un punto de vista global, la sociedad en su totalidad. El espacio que toma en consideración es amplio, integrador, panorámico, comprende todas las clases sociales y todas las relaciones individuo - sociedad. Trata varios tiempos de una época o de una biografía personal o familiar, y revive acontecimientos o procesos muy alejados en la historia para definir su presente problemático.

\section{El realismo dialéctico}

El realismo dialéctico se inicia con la publicación de la novela Tiempo de silencio de Luis Martín-Santos. ${ }^{22}$ Para entonces el realismo social había cumplido ya su ciclo vital y necesitaba una profunda renovación. Sin abandonar los problemas sociales, la novela del realismo dialéctico contempla estos problemas desde una nueva perspectiva y se enfrenta a ellos con una técnica que sería completamente innovadora. La figura del autor vuelve a dominar la novela, vuelve a ser omnisciente, deja de ser una simple cámara cinematográfica

${ }^{20}$ Nuevo porque sobrepasa la observación costumbrista y el análisis descriptivo del siglo XIX mediante el testimonio objetivo y social.

21 Sobejano, Gonzalo: «Direcciones de la novela española de posguerra», Boletín de la Asociación europea de profesores de español, núm. 6, Madrid, 1972, pp. 53-72.

22 Véase Buckley, Ramón: "Tiempo de silencio" de Luis Martín-Santos, Madrid, Alborada, 1988. 
que se limita a filmar la realidad, tal como lo era en el realismo social. El personaje colectivo, característico del realismo social, da paso de nuevo al protagonista individual. La uniformidad de estilo del realismo social da paso a una multiplicidad de puntos de vista, a una variedad de opiniones que constantemente chocan entre sí y producen un efecto esencialmente irónico.

La nueva dirección puede resumirse en un propósito básico: la desmitificación de España en todos los órdenes, tanto mentales y culturales como político-sociales. Esto supone un replanteamiento de la historia y de la tradición, el abandono de las falsas interpretaciones, o sea, la destrucción de los tópicos consagrados. Es un intento de renovación total, pues como dijo Martín-Santos, «prácticamente, en nuestra realidad espiritual española, está todo por destruir». ${ }^{23}$ Lo que se pretende es hacer un examen de la conciencia nacional, una radiografía que revele cómo «hemos parado a ser una ruina que, compasivamente, nos aplicamos a embellecer con adornos y fastos. Llamar ruina a la ruina, despojarnos de esos adomos sería un primer paso para salir de la decadencia en que nos encontramos». ${ }^{24}$ La misión de la novela sería, entonces, exponer esas ruinas con el propósito de renovar al hombre y todas sus actitudes.

\section{Tiempo de silencio}

Todos los estudiosos de la novela española coinciden en señalar que la primera novela renovadora de la narrativa de posguerra es Tiempo de silencio de Luis Martín-Santos. La fecha de 1962 es decisiva, entonces, en la evolución del género novelesco porque la editorial Seix Barral publica esta obra «irrepetible e inimitable» ${ }^{25}$, una de las obras que más ha influido en la novela española posterior. Tiempo de silencio representa desde el punto de vista de la estructura narrativa una total revolución por el tratamiento del material, diversidad de técnicas, enfoques, lenguajes, y constituye una completa renovación del género.

La novela que se escribe después de 1962 no puede prescindir de Tiempo de silencio. Esta novela es sin duda la obra que mejor resume la España de la posguerra, porque en ella se funden de manera especial y sintética los temas tópicos dentro de una visión total del ambiente español. La búsqueda de un nuevo lenguaje expresivo es lo que da a esta obra una cualidad especial. La novela capta y describe toda una época, la resume, la analiza y la problematiza y pretende representar la circunstancia histórica de España de todos los tiempos.

$\mathrm{Su}$ autor pertenece a la "generación herida" 26 , formada por los escritores que, siendo niños durante la guerra, conocieron los horrores de la paz y rompieron con sus escritos el opresivo silencio denunciando el estado de apatía y conformismo de la sociedad hipócrita en que vivían.

\footnotetext{
${ }^{23}$ Martín-Santos, Luis: Tiempo de destrucción, Barcelona, Seix Barral, 1983², p. 1.

24 Ibid.

25 Domenech, Ricardo: «Ante una novela irrepetible», Ínsula, núm. 187, Madrid, junio de 1962, p. 4.

${ }^{26}$ Matute, Ana María: «A Wounded Generation», The Nation, Londres, noviembre de 1965, p. 423.
} 
Martín-Santos había intentado poner en práctica un concepto totalmente diferente de la novela entonces vigente del realismo social. Intentaba escribir una novela que se basase en gran parte sobre el análisis psicológico, con valores simbólicos y no de fines exclusivamente utilitarios y propagandísticos.

Pedro Correa reduce a cuatro los hallazgos de esta novela singular:

- el intento de renovación temática, pues frente a la presencia casi exclusiva del hombre humilde en la novela del realismo social, en ésta desfilan varias clases sociales;

- el uso de varias técnicas narrativas, como monólogo interior, recursos del "nouveau roman", pequeños ensayos, digresiones y distintas perspectivas según la circunstancia y el tema;

- el lenguaje neo-barroco, apto para expresar el dinamismo interno de los monólogos;

- el hecho de que la novela se alza contra el prosaísmo, los coloquialismos y vulgarismos del realismo social, sin perder nada de la fuerza crítica de este movimiento. ${ }^{27}$

Tiempo de silencio es la primera novela española de la segunda mitad de este siglo que abre perspectivas enteramente nuevas en la concepción temática y sobre todo en la técnica estructural del arte narrativo. En este libro no se critican solamente las realidades sociales; mediante un procedimiento irónico se trata de suministrar las claves para comprender la malformación histórica española. El realismo de Martín-Santos trasciende las situaciones concretas, las explica. Porque ya no cabía la mera presentación de la realidad, sino habría que explicarla. Es la última gran novela sobre el infradesarrollo, escrita ya sobre supuestos del semidesarrollo. ${ }^{28}$ Como opina Martínez Cachero, se trata de una «novela de cambio y, también, de cierre y apertura». ${ }^{29}$ De cierre, porque representa el último gran texto de la novela social y, a la vez, de apertura porque significa la superación del mismo. El "engagement" persiste, pero sometido a una tensión estética, a una preocupación lingüístico-literaria que somete la crítica social a un tratamiento literario: la crítica se vuelve ironía, sarcasmo, metáfora, parodia. La novela vuelve su mirada crítica hacia la tradición literaria española para analizarla y al mismo tiempo para integrarse en su continuidad.

Hay en Tiempo de silencio un intento crítico muy parecido al de algunos miembros de la generación del 98, de interrogar el destino español, de encontrar el verdadero carácter nacional, si es que tal cosa existe, y de buscar nuevas salidas y soluciones para la sociedad española de su tiempo. Tiempo de silencio es, pues, entre otras muchas cosas, la culminación y superación del realismo social; su fuerza de denuncia social supera en mucho las directas y concretas acusaciones de las novelas anteriores. Además de ser crítica social de la sociedad

27 Correa, Pedro: «Narrativa española actual», Nuestro Tiempo, núm. 225, Madrid, marzo de 1973, pp. 38-40.

28 Morán, Fernando: La destrucción del lenguaje y otros ensayos literarios, Madrid, Editorial Mezquita, 1982.

29 Martínez Cachero, José María: La novela española entre 1936 y 1980. Historia de una aventura, Madrid, Editorial Castalia, 1985, p. 250. 
española, la obra representa también el complejo drama del hombre actual que se encuentra en el crítico estado de frustración, de soledad y enajenación.

Martín-Santos habló y escribió acerca de sus ideas sobre la literatura. Se sabe que tenía proyecto de crear realismo dialéctico. Aquilino Duque dice que Martín-Santos distinguía en la narrativa española de su época dos formas: por un lado, la picaresca o lo que él llamaba "realismo pueblerino" (la descripción de personajes vagos, no definidos por el contexto histórico); por otro lado, el realismo social o lo que él llamaba "realismo suburbano" (la descripción de personajes determinados por un contexto histórico contradictorio, de modo que aquéllos dejan de ser individuos). ${ }^{30} \mathrm{El}$ realismo dialéctico consisitiría, entonces para Martín-Santos, en la descripción de la relación contradictoria entre dos sistemas contradictorios no sólo en el contexto social, sino también en el contexto histórico. Ese realismo trataría de transformar, en presencia de una nueva realidad espiritual, el pasado y presente españoles. Llevada a cabo la desmitificación de las estructuras sociopolíticas y culturales, el novelista se encuentra con el problema espiritual del hombre, su soledad y angustia ante un mundo incapaz de crear cualquier valor. La carga ideológica y el consiguiente desvío del hombre ha sido, según Martín-Santos, uno de los fallos de la novela española de posguerra: «He aquí por qué la narrativa española, al cargarse de ideas sustituyendo al hombre por su circunstancia ha perdido paso específico y se ha alejado de la verdad artística». ${ }^{31}$

\section{Contexto histórico}

La acción de Tiempo de silencio se desarrolla en el otoño de 1949, según se deduce por la referencia a los «años del hambre» ${ }^{32} \mathrm{y}$, más concretamente, por la descripción de la conferencia de Ortega y Gasset, que tuvo lugar en aquellas fechas. Al situar la acción en el año 1949, Martín-Santos indica el deseo de volver al período más sombrío de la posguerra y a la época de su aprendizaje intelectual, ya que en aquel año terminó su especialización en psiquiatría en la Universidad de Madrid.

Varios críticos (Juan Carlos Mainer, Fernando Morán, Gemma Roberts, Janet Winecoff Díaz, José Ortega) han señalado la relación de Tiempo de silencio con la generación de 98 y Ortega y Gasset. Martín-Santos fue testigo de la polémica sobre el llamado "problema de España" durante sus años universitarios en Madrid, donde dos de los protagonistas (liberal el uno y reaccionario el otro) fueron sus profesores. El primero fue Pedro Laín Entralgo, falangista católico y humanista, catedrático de historia de la medicina y posteriormente rector de la Universidad de Madrid, autor de los libros La generación del 98 (1945) y España como problema (1949). El segundo fue Juan López Ibor, consejero nacional de falange espa-

30 Duque, Aquilino: «Realismo pueblerino y realismo suburbano. Un buen entendedor de la realidad: Luis MartínSantos», Indice, núm. 185, Madrid, junio de 1964, pp. 9-10.

31 Ibid., p. 9.

32 Martín-Santos, Luis: Tiempo de silencio, Barcelona, Seix Barral, 198931, p. 18. Las siglas TS y la mención de la páginas se referirán a esta edición definitiva de la novela. 
ñola, catedrático de psiquiatría, autor del libro El español y su complejo de inferioridad (1951). Martín-Santos también fue amigo de Rafael Calvo Serer, miembro de Opus Dei, autor del libro España, sin problema (1949), escrito como réplica al España como problema de Laín Entralgo. Laín sostenía que España necesitaba una renovación intelectual; Calvo Serer contestó que España no tenía ningún problema que no hubiera resuelto la Guerra Civil. A pesar de su amistad con Calvo Serer, Martín-Santos defendió la tesis de Laín Entralgo.

Tiempo de silencio demuestra que el problema de la España franquista consiste precisamente en su tendencia a negar la existencia de problemas, haciendo parecer «que no está tan mal todo lo que verdaderamente está muy mal» (TS, p. 20). La mayoría de los críticos que destacan la presencia de los noventayochistas y de Ortega y Gasset en la novela de MartínSantos lo han criticado por haber compartir sus ideas. Alfonso Rey ${ }^{33}$ cree que Martín-Santos toma la visión existencial de Ortega, y por tanto se extraña de Ortega (descripción del cuadro de Goya Scène de sorcellerie: Le Grand Bouc o Escena de aquelarre, el ambiente de la conferencia y la conferencia misma) que aparece en la novela. Ya en 1949, al asistir a la conferencia de Ortega, la actitud de Martín-Santos hacia éste era hostil. Martín-Santos expresó su hostilidad hacia la generación del 98 en un discurso pronunciado en San Sebastián en 1961 en el que critica severamente el pesimismo de los noventayochistas. ${ }^{34} \mathrm{Su}$ postulado más confuso ha sido su esencialismo: la explicación de los problemas del país en términos de un carácter nacional esencial que es producto de los tres factores determinantes del positivismo decimonónico (raza, medio ambiente, momento histórico). En la práctica, los noventayochistas suponen que el carácter nacional es producto sólo de la raza y del medio ambiente; y por éste entienden el contexto geográfico que, al igual que la raza, es un elemento fijo. La historia, que es elemento dinámico, la consideran como resultado del carácter nacional, y no como su causa. Descartan toda explicación de la realidad nacional en términos dinámicos, y se limitan a la búsqueda de causas fijas para poder justificar su pesimismo acerca de las posbilidades del cambio. Su visión antihistórica les lleva a crear el concepto de una esencia racial, que precede a la historia, y que persiste en contra de ella. Con esto, los noventayochistas intentan disociar el carácter nacional del fracaso histórico, o sea, el carácter nacional determina lo que no pasó en la historia y hubiera debido pasar.

La novela describe una sociedad que, en vez de hacer la historia, la deshace, al refugiarse en el pasado. España se ha convertido en un país «donde la idea de lo que es futuro se ha perdido hace tres siglos y medio» (TS, p. 290). El refugio en el pasado mítico no indica una actitud heroica, sino el miedo a enfrentarse con el fracaso. De ahí la desmitificación de la falsa gloria imperial que se lleva a cabo en la novela. Ésta demuestra que el problema de España no lo explica el análisis determinista del tipo racial, ni el análisis determinista del

\footnotetext{
33 Rey, Alfonso: Construcción y sentido de "Tiempo de silencio", Madrid, José Porrúa Turanzas, $1980^{2}$.

34 Martín-Santos, Luis: «Baroja - Unamuno», en Sabre la generación del 98. Homenaje a don Pepe Villar, San Sebastián, 1963, pp. 109-110.
} 
medio ambiente, sino el análisis dialéctico de la actitud española hacia el subdesarrollo. El problema de España lo constituye, no su inferioridad, sino su complejo de inferioridad.

\section{Tiempo de silencio como crítica total de la sociedad española}

La aparición en 1962 de la novela de Luis Martín-Santos fue recibida con sorprendida reserva o indiferencia por la crítica e ignorada prácticamente por el público. Sólo Ricardo Domenech destacó en la revista Ínsula su carácter renovador. Los críticos que posteriormente hablaron de ella destacaron sobre todo la preocupación formal de su autor, su intento de renovar los modos narrativos tradicionales. Este énfasis contribuyó a silenciar su sentido, a neutralizar la ironía destructora que la domina. Sólo los años posteriores al franquismo lograron señalar el valor real de esta novela de modo que hoy no se puede hablar de la narrativa española de posguerra o actual dejando de lado Tiempo de silencio.

En ella Martín-Santos intenta penetrar el fenómeno espiritual español mediante el realismo dialéctico, es decir, integrando dialécticamente el sujeto (héroe) y el objeto (mundo). Se sitúa el novelista en la complejidad socio-económica - lo que Sartre llama contextos debidos a la praxis de su tiempo ${ }^{35}$ para captar la realidad desde una forma total, para tener una visión macrocósmica de la sociedad.

Martín-Santos cree que la literatura tiene dos funciones respecto a la sociedad: la primera, realtivamente pasiva, trata de la descripción de la realidad social, y la segunda, la activa, consiste en la creación de una mitología al servicio de la sociedad. Y la función de la literatura como técnica de transformación social puede ejercerse de dos formas: destruyendo los mitos antiguos - función desacralizadora-sacrogenética, y creando nuevos mitos- función sacrogenética. Lo negativo, pues, encierra un carácter creador, positivo. Pero para todo pensar dialéctico no existe separación radical entre lo positivo y lo negativo - son dos aspectos de un mismo proceso dinámico.

La labor destructiva-constructiva que el novelista realiza en su novela afecta a los prejuicios y convencionalismos de la cultura española. Apartándose del objetivismo predominante por entonces en la novela española y de sus personajes colectivos, Martín-Santos vuelve al hombre de carne y hueso, en su obra abundan los tipos tomados del ambiente social, con perfiles prefectamente humanos. Sin embargo, a lo largo del texto persiste una visión metafórica, alegórica o simbólica de la realidad que trasciende la superficie externa de los hechos narrados. Hay un análisis de realidades históricas y actuales con un propósito trascendente.

35 «... en menos de tres décadas, el hombre se ha visto brutalmente relacionado, imperativamente relacionado, con lo que Jean-Paul Sartre llamaba los contextos. Contextos políticos, contextos científicos, contextos materiales, contextos colectivos; contextos relacionados con una disminución constante de ciertas nociones de duración y distancia (en los viajes, en las comunicaciones, en la información, en los señalamientos ...); contextos debidos a la praxis de nuestro tiempon.

Carpentier, Alejo: Tientos y diferencias, Barcelona, Plaza \& Janés Editores, 1987, p. 14. 
En su propósito de penetrar la realidad socio-cultural española a través de la dialéctica, la novela va desnudando las ideas, los prejuicios, convencionalismos, mitos y falsedades que dominan la vida del pueblo español. El análisis dialéctico abarca todos los estratos de la sociedad, desde el más bajo al más alto. La profundización de la realidad va más allá de la simple anécdota que es mínima. Sorprende la grandeza de la concepción, el ambicioso proyecto de recrear en la novela una sociedad en sus múltiples implicaciones, y de someter a revisión todos los mitos que a lo largo de los siglos iban determinando su existencia. Una concepción, en suma, que remite a la de James Joyce, puesto que aquí la realidad está recreada en una materia que básicamente es de lenguaje, de un lenguaje de contrapunto semántico de vocablos que parodia e ironiza por igual el estilo académico, los estereotipos de la clase media o baja como también los vanguardismos vanos del café Gijón.

Martín-Santos utiliza la narración en dos sentidos opuestos. Por un lado, intenta describir la realidad tal como es, pero lo que describe es la no realidad de la escasez o de la frustración de las posibilidades. Por otro lado, utiliza el lenguaje para dar una visión falsificada de la realidad, en términos de lo que no es. En los dos casos, lo que se describe es una presencia aparente que se refiere a una ausencia. La tarea del lector consiste en llenar esta ausencia de sentido. ${ }^{36} \mathrm{El}$ significado de la novela nace de la interrelación dialéctica entre lo que se describe o se dice, y lo que no se describe o no se dice. El significado del texto es dialéctico, al ser producto del juego de distintos niveles de sentido o del significado implícito. La intención del autor es que el lector asuma mentalmente la realidad compleja mediante la magia del lenguaje o de las innovaciones formales.

\section{Aspectos formales}

Tiempo de silencio es una obra en la que se mezcla un tema conocido con un estilo desconocido en España hasta entonces, una novela en la que se encuentran la tradición del género y los procedimientos vanguardistas: reducción espacial y temporal, empleo de monólogo interior, perspectivismo narrativo, sustitución de los capítulos por secuencias de extensión diversa, variedad de estilos, alusiones literarias y figuras retóricas en función paródica y desmitificadora, etc.

Su más curiosa innovación consiste en la adopción de un estilo paródico falsamente elevado que se aplica a la descripción de la realidad más mísera (TS, p. 52). Este contraste vuelve el estilo en estilo paródico que cuenta con la complicidad del lector. La parodia, la ironía o el sarcasmo suponen que en la conciencia del lector se encuentre la normal concordancia entre unos asuntos y unos lenguajes determinados, para que luego la disproporción tenga efecto. Martín-Santos entonces puede sugerir la posibilidad de que la realidad sea de

\footnotetext{
${ }^{36}$ Se trata del lector ideal que es capaz de entender el mensaje global del texto. Hay que subrayar la doble relación, implícita o explicita, que toda obra narrativa establece, por un lado, entre el autor y el virtual lector y, por el otro, entre el narrador y el narratario, sea éste designado o tan sólo sobreentendido.

Véase Prince, Géralde «Introduction à l'étude du narrataire», Poétique, núm. 14, 1974.
} 
otra manera. A pesar de rechazar el lenguaje transparente, el autor no abandona el realismo del todo, ya que se refiere al mundo real: Alfonso Rey ${ }^{37}$ hace notar que la novela alude constantemente a la realidad extraliteraria de la topografía madrileña y la historia nacional. Pero el significado de este mundo extraliterario al que la novela hace referencia, nace, no de lo que es, sino del abismo que lo separa de lo que pudo ser o de lo que se dice de él. El significado surge de una zona intermedia que se sitúa más allá de las palabras, en las realidades ocultas a las cuales el texto alude.

La narración de Martín-Santos está llena de alusiones y citas literarias, suscitadas habitualmente con intención caricaturesca. ${ }^{38}$ Podemos reconocer en ella a Quevedo y a Larra, las atrevidas metáforas al estilo gongorino (TS, p. 32), la presencia constante de Cervantes (TS, pp. 10, 75-77), de Ortega y Gasset (TS, pp. 162-163, 184)), las alusiones a Lope y Garcilaso, a Tirso (TS, p. 285) y Santa Teresa, las esperpénticas situaciones de Valle-Inclán, citas de Unamuno y de Machado. Del amplio campo de literatura universal son notables influencias de Joyce, Sartre, Faulkner, Dostoievsky, Kafka y Proust.

A lo largo del texto narrativo el autor usa la lengua de un modo muy peculiar mezclando lenguaje científico con las voces de argot, utilizando numerosas figuras retóricas o creando sus propias expresiones, bien uniendo palabras y frases por medio de guiones, bien formando nuevos derivados de otras palabras ya existentes, bien castallenizando palabras extranjeras. Su pluma tiene en el plano estilístico más relaciones con Quevedo que con otro autor anterior español, porque es con el genio caricaturizador quevedesco con el que emparenta de manera más directa.

La ordenación y disposición de los materiales de Tiempo de silencio es uno de los rasgos más llamativos. Porque al nivel del contenido temático Martín-Santos intenta penetrar los estados de conciencia de los personajes en particular y de la sociedad en general, llegando a la conclusión de que existe una evidente falta de cohesión y, consecuentemente, un estado caótico en la sociedad. Entonces, esta situación la intenta comunicar al lector también a través de la forma, en concreto, a través de la aparente naturaleza caótica del material narrativo. La novela tiene 63 fragmentos y el autor no utiliza ningún método para dividir estos fragmentos, a los que no llama capítulos, ni los enumera.

En la novela hay una complicada técnica de voces ${ }^{39}$ entremezcladas del personaje y del autor. La profunda desilusón del autor es la voz con fervor satírico que emerge con más fuerza; la otra voz narrativa cuenta el camino recorrido por el protagonista hacia una inexo-

\footnotetext{
${ }^{37}$ Rey, Alfonso: op. cit., 1980, p. 117.

38 La intertextualidad es el conjunto de las realciones que se ponen de manifiesto en el interior de un texto determinado. Todo texto es como mosaico de citas, todo texto es absorción y transformación de otro texto y cada lenguaje poético debe leerse, por lo menos, como doble.

Véase Kristeva, Julia: El texto de la novela, Barcelona, Editorial Lumen, $1981^{2}$.

39 Genette, Gérard: Figuras III, Barcelona, Lumen, 1989. Genette llama voz a la instancia narrativa, o sea, al procedimiento de enunciación (enunciación es el acto individual de la locución en el que se muestra el hablante) o de narración en el que se sitúa el narrador.
} 
rable confrontación con su culpa. Asimismo, la voz del autor consta de dos claras perspectivas: una que proviene de la situación social, económica y política de la España de aquel entonces; la otra de un concepto mitológico-teológico del hombre en la naturaleza. En cierto modo el rasgo más original de su técnica narrativa es la manera en que parece hablar objetivamente desde dentro de la mente del protagonista, unas veces totalmente integrado con él, y otras en las que se convierte en comentador objetivo cuyo papel es el de evaluar lo que va pasando en la profundidad de la conciencia del protagonista. Aunque deja hablar a sus personajes, Martín-Santos practica habitualmente un intervencionismo narrativo, sobreponiendo al relato continuos comentarios e interpretaciones, e imponiendo qué sentido debe darse a cada pasaje y a la novela en su conjunto. Su acto de comentar es un tipo de comunicación directa con el lector a fin de plantearle el problema en términos generales.

En Tiempo de silencio se combina un narrador omnisciente ${ }^{40}$ y un narrador-personaje; el lector experimenta alternativamente la sensación de alejamiento y la participación inmediata. El alejamiento le permite observar las fuerzas sociales que determinan el modo de ser del individuo, y la identificación le obliga a compartir en el nivel subconsciente el efecto de estas fuerzas sobre el individuo. Muy novedoso es el empleo de la segunda persona, que implica un desdoblamiento del yo en otro yo reflexionante, que aparece en el relato después de la narración impersonal con infinitivo y narración autobiográfica en primera persona (TS, pp. 215-221). Tal cambio de perspectiva aparece con frecuencia a lo largo del texto, pero la perspectiva global de la novela es la del autor que controla la alternancia de recursos narrativos. A esta diversidad de perspectivas hay que añadir también el monólogo interior con el que se revelan cuatro personajes de la novela (Pedro, la dueña de la pensión, Cartucho y Similiano, el detective). Cada uno con su lenguaje propio, personal, reflejo de sus circunstancias y caracteres. Es evidente que Martín-Santos tenía conciencia de que «saber cómo habla un personaje es saber quién es, que descubrir una entonación, una voz, una sintaxis peculiar es haber descubierto un destino»). ${ }^{41}$ La novela comienza y termina con monólogos interiores del protagonista, aunque quizá los ejemplos más acabados sean los de la patrona de la pensión (TS, pp. 20-29) y Cartucho (TS, pp. 54-57). En general, «no se trata de una conciencia deformante, como la de los idiotas y locos de Faulkner, sino de una conciencia inteligente y responsable». ${ }^{42}$ Pero lo más característico es lo que Janet Winecoff Díaz ${ }^{43}$ llama monólogo dialéctico, que consiste en una combinación de confesiones del personaje, relato de acciones y juicios del autor sobre lo que está relatando y sobre lo que el personaje

40 Como ejemplo extremo de ese intervencionismo narrativo es el diálogo en el que llegan a omitirse casi todas las palabras de los interlocutores, sustituidas por paréntesis que sintetizan lo que cada personaje se supone va a decir; se trata del diálogo entre Pedro y el policía (TS, p. 207).

41 Borges, Jorge Luis: La poesia gauchesca, Buenos Aires, Discusión, 1957, p. 4.

42 Clotas, Salvador: Prólogo a "Apólogos y otras prosas inéditas" de Luis Martin-Santos, Barcelona, Seix Barral, 1970, p. 12.

43 Winecoff Díaz, Janet: «Luis Martín-Santos and the Contemporary Spanish Novel», Hispania, núm. LI, University of Massachusetts, U.S.A., pp. 232-238. 
piensa. De este modo se tiende a borrar distancias, viendo el mundo y las cosas desde el punto de vista del personaje e identificándose con él.

En la elección del argumento se separa Martín-Santos del principio aristotélico que da prioridad a la acción sobre el estudio de los personajes. En vez de encontrar seres humanos superficiales a la medida de su ideología, nos da personajes que sufren dudas y contradicciones. Se trata de un procedimiento narrativo al estilo cinematográfico ("slow-motion"), que consiste en el detenimiento de la acción para presentar la elasticidad del momento. En la narrativa esta técnica se define como morosidad ${ }^{44}$ que permite al autor acumular la mayor cantidad de detalles. Para conseguir la lentitud de movimiento el autor no sólo reduce su novela a un tiempo y espacio limitados, sino que mueve hechos y seres simultáneamente. De este modo la novela obtiene a parte del valor vertical un amplio sentido horizontal.

Cuando la realidad se esencializa, aparece el símbolo. La novela incluye determinados elementos que ya están dotados de valor simbólico en la tradición cultural española (los toros, el cuadro de Goya "El Gran Buco") o se les atribuye ahora el valor simbólico (el cáncer, la pescadilla mordiéndose la cola).

Martín-Santos defiende un realismo basado en la contradicción del medio social y del individuo; su novela constituye un acto de rebeldía contra el naturalismo fotográfico, populista que caracterizaba la mayoría de la producción novelística de la década de los cincuenta. El contraste en Tiempo de silencio sirve para evidenciar y descubrir lo grotesco y lo ridículo de la idea que encierran las expresiones contrastadas. Esta técnica de luz y de sombras sirve para destacar el aspecto sórdido de la realidad, descubriendo que el mundo de la claridad no es superior al de las sombras. La novela traduce la falta de sentido del vivir español de aquel entonces.

«En esta obra el afán por mostrar una realidad objetiva es sustituido por el sarcasmo utilizado casi sistemáticamente como forma de dar a una realidad anodina calidad expresiva. Detrás de este sarcasmo que informa todo el libro, tanto desde el punto de vista temático como estilístico, se descubre un atroz pesimismo no sólo respecto a España y a su realidad social sino también a toda dimensión humana y existencial». 45

\section{Señas de identidad}

Otra novela del realismo dialéctico que destruye los mitos de la España sagrada con un impulso decidido es Señas de identidad de Juan Goytisolo. Para Carlos Fuentes, Goytisolo «significa el encuentro de la novela española con la que se escribe en Hispanoamérica». 46

\footnotetext{
44 Véase Villarino, Alfonso: «Tiempo de silencio, novela morosa», Cuadernos Hispanoamericanos, núm. 308, 1976, pp. 146-156.

45 Clotas, Salvador: op. cit., 1970 , p. 9.

46 Fuentes, Carlos: La nueva novela hispanoamericana, México, Cuadernos de Joaquín Mortiz, 1969, p. 78.
} 
El escritor mexicano sostiene que Goytisolo «emprende la más urgente tarea de la novela española: destruir un lenguaje viejo, crear uno nuevo y hacer de la novela el vehículo de esta operación». ${ }^{47}$ Entonces, emprende el complejo proceso de destrucción de la lengua y de construcción de otra nueva que pueda abarcar realidades completamente distintas de las que tradicionalmente elaboraron en la novela española de postguerra. Con Señas de identidad Goytisolo se ha propuesto hacer una obra de ruptura válida para los novelistas de toda la generación, una obra modelo que sólo indicara direcciones de salida del callejón en el que la novela española de la época se sintió encerrada.

Esta novela intenta socavar los falsos valores establecidos, destruir viejos convencionalismos y derrumbar la parte más inmóvil de la tradición hispánica. La tarea del escritor es demistificar de manera sistemática los valores que se han fosilizado con el tiempo hasta perder su sentido y convertirse en mitos que actúan sobre la vida hispánica sin ser cuestionados por nadie. Para tal tarea era necesario acabar con el lenguaje que había sido el vehículo de expresión. Así, junto con la agresión ideológica se produce la agresión lingüística que ataca las tradicionales formas del buen decir académico. Juan Goytisolo necesitaba un lenguaje propio con el que pudiera describir su particular realidad en el doble plano socio-lingüístico.

España y su contorno político, social y cultural son el tema principal de la obra de Goytisolo. En Señas de identidad asistimos al intento de revelación de la realidad que subyace bajo la máscara deformadora de las instituciones españolas y a la reconstrucción de una nueva sociedad regida por nuevos valores. La génesis de España hay que concebirla como «obra de varios siglos de represión de innumerables frustraciones de todo orden» ${ }^{48}$ La nación española ha sido y es el producto de un proceso de mitificación iniciado desde la Edad Media cuando Castilla impone, por la superioridad en las armas, la supremacía frente a los hebreos y musulmanes. Esa imagen del pueblo conquistador, portador de valores espirituales basados en la religión católica, se ha tratado de mantener idéntica a lo largo de los siglos como beneficio de la casta dirigente. ${ }^{49}$

\section{Novela de experimento y de ruptura}

Señas de identidad abre una nueva etapa en la carrera literaria goytisoliana, parece como su autobiografia después de un momento de transformación. Esta novela es un punto de transición de una escritura que ha alcanzado un punto muerto y que reconoce que su única salida es la ruptura con su pasado anterior. El texto recoge ecos de personajes, situaciones, temas y técnicas que aparecen en las novelas del período anterior. Pero al mismo tiempo es el resultado de la búsqueda de nuevas formas narrativas, es el espacio que acoge la ruptura con una tradición de novelar y la incorporación de una nueva forma de narrar. De esta forma para

\footnotetext{
47 Ibid., p. 81.

48 Doblado, Gloria: España en tres novelas de Juan Goytisolo, Madrid, Nova Scholar, 1988, p. 82.

49 Véase Castro, Américo: La realidad histórica de España, México, Porrúa, 1971.
} 
Goytisolo Señas de identidad representa un momento de modernidad porque significa una desviación radical de las novelas anteriores. El ataque a los diversos discursos españoles tiene emisor: un individuo que tras sufrir un ataque cardíaco decide examinar su vida pasada, y llega a la conclusión de que la única forma en que podrá liberarse del sentimiento de impotencia es mediante la destrucción del orden mitificador español. En la relación dialéctica entre el hombre y la sociedad a partir de esta novela cobra mayor importancia el hombre como fundamento de la sociedad. La libertad es su esencia y su problema, se convierte en responsable de sus decisiones y en combatiente por ellas.

\section{Elaboración del tema}

La novela está construida en torno a un personaje, Álvaro, héroe novelesco de grandes proporciones, cuya vida aparece en un "flashback" muy largo y se nos desteje en una serie de círculos concéntricos hacia atrás cuyo centro es el tiempo presente del protagonista.

Los datos personales básicos de la vida de Álvaro coinciden con los de Goytisolo. Ello contribuye, junto con el carácter de crónica de la España contemporánea, al tono autobiográfico de la novela. Como Goytisolo, Álvaro es un español joven que procede de una familia de origen norteño afincada en Cataluña. Ha abandonado España para trasladarse a París donde reside actualmente. Sin embargo la novela Señas de identidad trasciende mucho los límites de la autobiografía. Se convierte en un análisis comprensivo de las generaciones jóvenes de posguerra, de sus características diferenciales y los de la sociedad en torno a ellos. Álvaro es un portavoz que actúa y expresa las frustraciones, el dolor y la rebeldía de todos los españoles contemporáneos que, como él, han tenido que vivir unas circunstancias extraordinariamente difíciles.

La novela comienza con el monólogo interior de Álvaro que marca las coordenadas del texto en unos límites que van de su interior al entorno social en un vaivén que facilita el conocimiento de los estímulos externos y la respuesta del personaje. Esto hace que el lector y el personaje se conozcan simultáneamente, el proceso de desmitificación se realiza al mismo tiempo para ambos.

Los motivos de la novela son de dos tipos, exteriores e interiores. Los primeros proceden de la sociedad, los segundos, llamados las Voces, pertenecen al desarrollo psicológico del personaje. La alternancia entre las Voces y el desprecio del personaje hacia ellas, en una doble visión del problema, va a ser la técnica básica de la obra. Aunque el monólogo interior es el medio principal de la presentación de Álvaro, éste también es presentado en tercera persona, sobre todo en el capítulo $\mathrm{V}$, donde analiza el fracaso y desencanto ante las actividades de los exiliados y la vida de los emigrantes. Psicológicamente su retroceso, al comienzo del texto, va hacia la niñez y sus sentimientos en busca de sus raíces. A lo que no está dispuesto es encontrar la verdad en el conformismo. Busca la razón y causa de unas circunstancias, por eso está condenado al enfrentamiento con los demás.

La huida de la familia es la negación de todos los valores tradicionales que representa el rechazo global de una sociedad que los ha posibilitado. El descubrimiento de la realidad lo 
realiza Álvaro en sus viajes por el país. El viaje a Yeste le pone en contacto con la violencia ciega que acabó con su padre y que masacró a unos campesinos por ejercitar su derecho al trabajo. A esa realidad histórica se le superpone un presente absurdo. Porque la vida del español contemporáneo se desarrolla entre la sumisión y el fanatismo y sed de sangre en salvajes fiestas de la corrida. Perdido el sentido del trabajo y de la libertad de los campesinos muertos en 1936, desaparecidos el equilibrio y criticismo, reina la barbarie en todos los niveles de la vida. En el extranjero están los emigrantes que se refugian en la mitificación de su país con la idea de haber perdido un paraíso. Entre dos extremos Álvaro siente una completa soledad, la de vivir en un mundo diferente, la angustia de encontrarse perdido entre familiares y compatriotas. En un mundo contradictorio y extremista, donde cada ser vive con sus mitos sumergido en la masa, él se siente desarraigado y asombrado por la actitud social.

La línea temática de la novela gira, entonces, en torno al problema de la enajenación que divide su personalidad. Álvaro desde el exilio interno, paralelo al externo, busca la raíz interior para descubrir sus ser auténtico, ordenando y analizando las distintas partes que componen el rompecabezas de su vida.

La crítica de España y del mundo occidental es muy feroz y dura en la novela. Álvaro en un principio ataca a España por estar con retraso respecto a Europa, tanto económica como políticamente, diciendo que su país «se había convertido en un torvo y somnoliento país de treinta y pico millones de policías no uniformados». ${ }^{50}$ Esta es la visión que Álvaro tiene de España como país anacrónico y primitivo con habitantes como miembros de una tribu. Pocas personas se salvan de la crítica mordaz del narrador, pues se opone a todo el mundo, desde las más altas esferas de la sociedad (dice que un rey es una "decorativa y vistosa pieza de recambio», SI, p. 36) hasta las más bajas, los trabajadores españoles que huyen de la pobreza para ir a buscar trabajo en Francia. No menos violenta es la burla de los que cruzan los Pirineos en dirección opuesta a estos trabajadores, es decir de los millones de turistas europeos que como antiguos conquistadores invaden España cada verano en busca del sol:

«Imaginaste al caballero Don Quijote con su lanza su yelmo y armadura cociéndose al sol de esta bochornosa mañana de agosto de 1963 en medio de las bárbaras caravanas de Hunos Godos Suevos Vándalos Alanos que con gafas oscuras shorts sombreros de paja botijos porrones máquinas de fotografiar castañuelas sandalias alpargatas de payés banderillas blusas de nailon pantalones tirolesas camisas estampadas contemplaban la perspectiva de la ciudad agrupados en torno de los catalejos bajo la mirada vigilante de los guías y chóferes de los autocares» (SI, p. 332).

Álvaro es, entonces, un personaje fundamentado en la crítica social, en la destrucción total de los valores más arraigados en la tradición española. Por eso siente una necesidad profunda de salir de este mundo caótico español y su exilio hay que entenderlo de un modo simbólico.

50 Goytisolo, Juan: Señas de identidad, Madrid, Narrativa Mondadori, 1991, p. 189. En adelante las citas del texto estarán seguidas de las siglas SI y del número de la página correspondiente. 


\section{Aspectos formales}

Existe una relación tan estrecha y cohesiva entre el protagonista y la España presentada a lo largo de la novela, que los distintos procedimientos narrativos utilizados en el texto, tales como el empleo de distintas personas narrativas, la eliminación de la puntuación convencional, los saltos temporales, yuxtaposiciones irónicas, versos libres, monólogos interiores y pasajes intertextuales, por fuerza tienen que determinar la perspectiva del lector dirigiéndola hacia el personaje y su país.

Lo primero que se destaca en Señas de identidad es la utilización de todas las personas verbales. Cada una de ellas capta un punto de vista de los acontecimientos. Así tenemos ya desde la primera página el uso de nosotros. La primera persona del plural abarca la totalidad de lo instituido, lo oficial intocable, bien como denuncia de la actitud del personaje y del régimen, bien como defensa de una postura. Nosotros supone la pluralidad de "yo-es" que forman parte del conjunto del país.

La primera persona del singular es utilizada en los diálogos, bien como actualización de un diálogo pasado o un presente de la vida del protagonista.

La tercera persona, sea del singular sea del plural, designa la realidad externa y la objetivación.

El espacio literario correspondiente al tú se puede determinar por exclusión porque no le pertenece ni lo externo ni el presente. Se eliminan así el pasado externo (guerra), el presente externo (París), lo institucional (las Voces) y los documentos. Lo que queda es lo que el personaje considera su núcleo vital. Para Francisco Ynduráin ${ }^{51}$ el antecedente en este aspecto es Martín-Santos. Señas de identidad supone la toma de conciencia de unos actos situados y contemplados desde el presente. No se trata, pues, de un nivel propiamente lingüístico, sino de un recurso literario mediante el cual se producirá la objetividad del yo que indica una personalidad plena y subjetiva, con el fin de distanciarse de la realidad para un análisis más correcto.

En su libro Problemas de la novela Goytisolo señala cómo el empleo del monólogo interior presenta «la realidad de un modo informe y como filtrada» y así «obliga al lector a prestar su colaboración para establecerla». ${ }^{52}$ Es curioso observar que este procedimiento no vuelve a aparecer en la novelística goytisoliana hasta Señas de identidad, demostrando cómo tarda el autor casi una década en realizar con toda plenitud una estética formulada en 1959.

Señas de identidad es la obra compleja que exige un lector activo. Toda la novela está caracterizada por una ruptura temporal, espacial y psicológica. El texto es un complicado juego de perspectivas en donde se unen armoniosamente tres, el punto de vista del autor, del personaje y del lector. La clave para entender la primera perspectiva narrativa, la creación de la novela por Juan Goytisolo, se manifiesta en los Archivos del autor en Boston Univer-

\footnotetext{
51 Ynduráin, Francisco: «La novela desde la segunda persona» en Gullón, Agnes y Germán: Teoría de la novela (Aproximaciones hispánicas), Madrid, Taurus, 1974, pp. 205-207.

52 Goytisolo, Juan: Problemas de la novela, Barcelona, Seix Barral, 1959, p. 36.
} 
sity, donde se reúnen en una carpeta especial las fuentes externas que entran en el cuerpo mismo de la novela. De la carpeta que trata las fuentes utilizadas en la construcción de Señas de identidad, Goytisolo hace el siguiente comentario: «He aplicado el procedimiento de incorporar materiales reales en el cuerpo de la novela - un poco como los pintores que, en lugar de pintar un caracol marino, incrustan en el cuadro un caracol realy. ${ }^{53}$ Mediante las distintas fuentes es posible reconocer distintos pasos que fueron necesarios para la construcción de la obra. La perspectiva del personaje coincide con la del autor en la fabricación de una realidad interior semejante a la exterior. Todo el proceso se parece al cuadro Las meninas de Diego Velázquez, donde, de igual forma se presenta el producto final y el proceso creador que lo ha realizado. Existe una tercera perspectiva, la del lector, que también se sirve de las fuentes de la novela para ordenar los acontecimientos y reconstruir los elementos principales de la vida del protagonista. Entonces toda la novela viene a ser un instrumento de conocimiento para los tres agentes. ${ }^{54}$

Junto con los procedimientos narrativos mencionados existe otra técnica importante en Señas de identidad que llega a ser fundamental en el proceso creador de Goytisolo a partir de esta novela. Se trata de la intertextualidad. Los autores predilectos son Machado, Quevedo, Larra y Cernuda que pueden entrar en el texto con sus citas directas, en función de orientar al lector sobre el sentido del texto que sigue y rendir homenaje al citado, o se incluyen sus ideas como materia viva, como síntesis que se armoniza con el texto de Goytisolo. Referencia a Mariano José de Larra: «El pueblo se le aparecía como un gigantesco cementerio en donde cada ventana era una tumba, cada edificio el mausoleo de un sueño o una esperanza. [...] el cementerio estaba fuera tu ciudad era el cementerio" (SI, pp. 171-172, 336). La presencia de Cernuda, uno de los maestros predilectos de Goytisolo, sirve como un apoyo para intensificar el tono personal de ruptura.

En Señas de identidad las estructuras espacio-temporales se dividen en capítulos. Cada uno de ellos se concreta en una época y un espacio. Siguiendo a Gérard Genette ${ }^{55}$ se pueden destacar desde el punto de vista de la relación entre discurso e historia (tiempo narrativo y tiempo real) los siguientes movimientos narrativos:

- las pausas descriptivas en las que el tiempo del discurso es más amplio que el tiempo histórico. Así se marca un tempo lento con el fin de analizar el sentimiento del personaje ante los acontecimientos. De esta forma tales pausas se convierten en puntos de reflexión que recogen los resultados de su análisis (comienzo y final de los capítulos).

- El diálogo, planteado anteriormente como una igualdad entre el tiempo del discurso y de la historia, cobra ahora un nuevo valor que se emplea para producir alte-

\footnotetext{
53 Gould Levine, Linda: Juan Goytisolo: la destrucción creadora, México, Juan Mortiz, 1976, p. 71.

54 Véase también Curutchet, Juan Carlos: «A partir de Luis Martín-Santos» en Cuatro ensayos sobre la nueva novela española, Montevideo, Editorial Alfa, 1973.
}

55 Genette, Gérard: op. cit., 1989. 
raciones temporales, de aceleración del tempo del discurso. Así, por ejemplo, ocurre con el diálogo de Dolores y Álvaro que cubre varios años en cuatro páginas (SI, pp. 277-280).

- La elipsis que en Señas de identidad es explícita porque entre los capítulo queda un vacío temporal que es producto de la selección ejercida por el narrador.

De esta forma se rompe con los aspectos temporales y espaciales de la novela decimonónica creando nuevas posibilidades. Las características narrativas mencionadas hacen que la novela va adquiriendo un tempo lento a medida que avanza, por lo que el interés no viene producido por la intriga o la trama, sino por el valor de la palabra y la articulación del discurso.

La utilización de recursos tipográficos ha sido siempre abundante en las novelas de Goytisolo, desde los diferentes tipos de letra hasta las interlíneas, espacios en blanco, la eliminación de puntuación, etc. Hay dos tipos de la letra cursiva, la interna y la externa. La primera la utiliza Goytisolo para indicar una reflexión del personaje o del narrador. La bastardilla externa se utiliza en palabras que no forman parte de la conciencia, que son términos que se reciben de otros medios, como los informes (por ejemplo, Diario policial en el capítulo IV), la radio, los apodos o los extranjerismos. Su empleo más claro para el lector se produce cuando separa lo que el personaje oye de lo que está pensando, como sucede en el diálogo de Dolores con sus sobrinos frente al pensamiento de Álvaro (SI, pp. 285-293). Goytisolo utiliza también las mayúsculas que se utilizan en el caso de impresos, de epígrafes; o las omite al principio de párrafos para contradecir al reglamentado de la Real Academia. Desaparecen los signos de puntuación cuando es indicada una continuidad en el discurso y es complementada con los espacios en blanco que señalan el cambio del tema o de perspectiva. Aparecen secuencias en idiomas extranjeros, neologismos y palabras entre guiones que refuerzan el carácter cosmopolita de la narración o constituyen una burla de las insuficiencias expresivas de la lengua española. Todos los recursos lingüísticos y gramaticales utilizados en la novela pueden ser considerados como recursos destructores en función desmitificadora.

\section{Señas de identidad - desmitificación del ethos español}

Juan Goytisolo se enfrenta al discurso literario español con el objetivo de problematizar textos que él considera se han rendido dócilmente al poder. Muchos escritores, según Goytisolo ${ }^{56}$, han utilizado su escritura con el propósito de representar los conceptos mitificadores sobre la preservación de la esencia y la uniformidad de lo español.

El mito respalda y recrea la tradición a fin de reafirmar los valores y principios del poder. Pero una vez que el individuo comprende que la homogeneidad es una máscara de las contradicciones presentes en la sociedad, la tradición se revela utilizada por las fuerzas dominantes para guardar su posición. La desmitificación pretende mostrar cómo los discursos

56 Véase su ensayo «Literatura y eutanasia» en El furgón de cola (op. cit.) donde hace referencia a la relación entre la generación literaria de posguerra y el régimen. 
mitificadores están regulados por una serie de códigos que sus usuarios utilizan inconscientemente. La desmitificación es el desenmascaramiento de esta inocencia. La literatura también es propensa al proceso mitificador y a la tarea desmitificadora. La mitificación ocurre cuando el texto se muestra como la representación de significados ya establecidos y reiterados en otros discursos, sin ningún cuestionamiento de su significación. El texto se convierte en discurso estático que no necesita la colaboracón del lector. El discurso desmitificador le previene al lector que no tiene que satisfacerse con la interpretación, que no tiene que buscar un significado que sea el únicamente válido. Con la labor desmitificadora se superan las limitaciones que han sido impuestas por varias tradiciones, de género, de lectura o de significación.

En Señas de identidad hay una problematización de las normas y relaciones de poder exteriores al texto, y de las que lo regulan desde su interior. Al mismo tiempo, el discurso goytisoliano emprende una tarea liberadora. Lo árabe, lo homosexual, lo políticamente subversivo, los discursos que poseen el mayor número de prohibiciones en la España castiza y franquista, son los que Goytisolo elabora en su texto. El autor desea minar los mitos de origen, de la normalidad, de la verdad que son utilizados como agentes represivos en beneficio del sistema de fuerzas dominante.

La escritura goytisoliana va en contra de las estrategias de dominio utilizadas por el poder, pero reconoce que su única posibilidad de lucha se inscribe dentro del terreno textual. El texto suyo desea reescribir la historia, el mundo del texto mitificador, lo acoge con el propósito de perturbar su significación. La parodia, la sátira y el plagio son estrategias mediante las que se ridiculiza el texto mitificador, que es desplazado de su posición privilegiada. La problematización efectuada por Goytisolo tiene el propósito de formar un nuevo orden, una nueva cultura y una nueva historia.

Las páginas de Señas de identidad surgen del fondo mismo de Goytisolo en combinación armoniosa con las transformaciones de la sociedad española y el deseo de crear un nuevo arte en España. De esta manera, más que cualquier otra obra escrita por Goytisolo en el período entre 1954 y 1966, Señas de identidad parece ser una novela que el autor tenía que escribir, con una necesidad imprescindible, para poder enfrentarse con una serie de temas, fragmentos y teorías que le han obsesionado desde sus primeras obras y que han exigido una estructura múltiple de coexistencia simultánea.

\section{Cinco horas con Mario}

El tercer paso importante hacia el realismo dialéctico de la novela española de posguerra fue dado por Miguel Delibes. Desde 1948, fecha de su revelación, Delibes ha publicado muchas novelas, libros de cuentos y esnayos. Sus obras aparecen con regularidad, sin apresuramiento ni largas pausas. Los críticos observan el cambio que se ha notado con la publicación de cada libro nuevo, superación de un realismo minucioso casi naturalista por otro realismo poético y humorístico más estilizado, eliminación de descripciones superficiales, 
depuración del lenguaje. Delibes ha ido acercándose cada vez más a los problemas inmediatos de su sociedad y de su tiempo, ha ido pasando de una problemática existencial relativamente abstracta hacia una problemática social muy actual y concreta que le coloca en el mismo frente en que han operado Luis Martin-Santos y Juan Goytisolo.

Para Alfonso Rey ${ }^{57}$ el tema básico de la novelística de Delibes es una visión de la realidad hecha a la medida del habla particular de un protagonista. De acuerdo con ella se consiguen las características siguientes: las descripciones modelan el punto de vista del narrador, la importancia de la acción se subordina a ese punto de vista, los personajes secundarios aparecen definidos por unos pocos rasgos, ciertas situaciones emotivas se repiten y por repetición se intensifican, y se va formando una relación progresiva entre el autor (imperceptible) y un protagonista (omnipresente). El progreso se da desde el distanciamiento hacia la aproximación y la compenetración; desde el extremo en el cual aún las preocupaciones más personales de Miguel Delibes aparecían tratadas como si le fueran ajenas (La sombra del ciprés es alargada, 1948) hasta el otro extremo en el que incluso los caracteres y modos de ser más extraños a la personalidad del escritor se manifiestan tan inmediatos que dan la impresión de serle propios (Carmen Sotillo en Cinco horas con Mario, 1966).

Ramón Buckley ${ }^{58}$ observa que Delibes siempre se ha ocupado en sus novelas del hombre como individuo, buscando los rasgos que hacen de toda persona un ser único. Esta singularidad la expresa en cada uno de sus personajes a través de tres cualidades esenciales: un nombre, una manía y un camino, como lo afirma Amparo Medina-Bocos. ${ }^{59}$ En esta misma línea se expresa también Fernando Morán ${ }^{60}$ al señalar que el personaje delibeano está condicionado en su evolución por su temperamento y su destino. Uno de los mayores aciertos de Delibes novelista existe en haber sido dejar hablar a sus personajes. Algunos críticos, por ejemplo Edgar Pauk ${ }^{61}$ y Ramón Buckley ${ }^{62}$ han analizado la evolución del escritor en este sentido, desde las primeras novelas en que la presencia del narrador es absoluta, hasta lograr de manera paulatina la desaparición casi total que puede observarse en Cinco horas con Mario, donde el lenguaje de una mujer de clase media se muestra directamente.

Esta novela corresponde a la «expresión de la situación de cambio, de polémica y de crisis del realismo [...] crisis que obligará a asumir las insuficiencias de la simplicidad, de una visión lineal y unidimensional de la realidad». ${ }^{63}$ Cinco horas con Mario es una obra de

${ }^{57}$ Rey, Alfonso: La originalidad novelistica de Delibes, Santiago de Compostela, Universidad de Santiago de Compostela, 1975.

58 Buckley, Ramón: Problemas formales en la novela española contemporánea, Barcelona, Península, 19732, pp. 85-89.

59 Medina-Bocos, Amparo: Delibes Miguel (1920-), "Cinco horas con Mario", Madrid, Alhambra, 1987.

${ }^{60}$ Morán, Fernando: Novela y semidesarrollo, Madrid, Taurus, 1971.

61 Pauk, Edgar: Miguel Delibes: desarrollo de un escritor (1947-1974), Madrid, Gredos, 1975.

62 Buckley, Ramón: op. cit., $1973^{2}$.

63 Díaz, Elías: Pensamiento español contemporáneo, 1939-1975, Madrid, Edicusa, 1978², pp. 237-238. 
oposición al régimen bajo el que apareció. La gran habilidad de Delibes consiste en analizar desde dentro de un personaje las ideas y la mentalidad de las clases medias españolas, que apoyaban la inercia y estaban en contra de los cambios en la sociedad. Esta novela también reacciona muy sensiblemente a la forma literaria de la época, al realismo social, a sus tabúes. Lo hace «con estrategia de una inocencia fingida [...] que le permite entenderse con los lectores tras la espalda de las instancias de controb).${ }^{64}$ Es conocido que Delibes quiso engañar a la censura:

«En Cinco horas con Mario me paré a las cien cuartillas, porque aquello no funcionaba con Mario vivo. Afortunadamente esa vez vi la luz, ayudado por la censura y en esa ocasión ésta me sirvió para que encontrara la solución: matar a Mario y verlo a través de su mujer, cuyos juicios eran oficialmente plausibles. Si no llego a encontrar esta solución hubiera quedado el proyecto a medias, lo hubiera abandonado». .65

Con su novela Delibes se refiere no sólo a un caso aislado, a unas disonancias matrimoniales, sino a una situación general, a la política oficial de la época. La mentalidad de la clase media conservadora, que ha sido la que ha apoyado esencialmente el régimen, se muestra desde dentro, es decir partiendo de sí mismo, en forma de un autorretrato aparentemente ingenuo. Éste es tan auténtico que en él reside el verdadero ingenio de la obra - la crítica del régimen desde el mismo régimen y no desde fuera. Además, esta obra es difícilmente atacable porque el crítico del régimen permanece mudo y sólo se expresa por mediación de una Carmen típica, a cuya concepción del mundo el autor no hace explícitamente la menor objeción. Rara vez se ha esquivado la censura con tanta habilidad como en Cinco horas con Mario.

\section{Sobre el contenido y la estructura}

Se trata de una novela en la que apenas hay argumento en sentido tradicional. ${ }^{66} \mathrm{La}$ obra comienza con la reproducción facsímil de una esquela como cualquier otra que pueda encontrarse en un periódico español de los años sesenta. Suscriben la esquela su desconsolada esposa Carmen, sus cinco hijos y resto de la familia doliente. Con esta primera página el lector penetra inmediatamente en el mundo familiar de Mario, que le es presentado ya muerto.

El curioso comienzo de la novela indica a la vez el comienzo de una narración marco. En las páginas del prólogo se describe el mundo exterior que rodea a Carmen en los momentos posteriores al descubrimiento del cadáver de Mario. Este cuadro ofrece ya un primer

\footnotetext{
${ }^{64}$ Neuschäfes, Mercedes y Hans-Jörg: "“Cinco horas con Mario", veinte años después y desde fuera», Los Cuadernos del Norte, núm. 34, Oviedo, 1985, p. 29.

65 Goñi, Javier: Cinco horas con Miguel Delibes, Madrid, Anjana Ediciones, 1985, pp. 49-50.

66 Véase Sobejano, Gonzalo: Estudio introductorio a "Cinco horas con Mario" - versión teatral, Madrid, Espasa Calpe, $1981^{2}$.
} 
indicio sobre la relación entre los esposos, sobre el ambiente social en que se movían y sobre el lenguaje que se habla en este ambiente y que será el verdadero protagonista de la novela.

Tanto el prólogo como al final el epílogo presentan de una manera teatral el ambiente de la casa. Al enfocar el velatorio de Mario, Delibes pinta unas escenas donde cada personaje conoce muy bien el papel que allí representa y las palabras que debe decir para que la representación resulte perfecta. Las apariencias que tanto obsesionan a Carmen se cubren a la perfección. Ella cumple a pie de la letra las costumbres del rito funeral: el luto, las frases de agradecimiento, la preocupación por parecer una viuda. Escritos en tercera persona y único momento en que se introduce también el diálogo, prólogo y epílogo son verdaderos actos teatrales. Los personajes son como muñecos que entran y salen, con movimientos, gestos, expresiones, tono de voz muy determinados. El narrador actúa como un verdadero director que ilumina la escena desde distintos ángulos.

El prólogo es un desarrollo de la esquela, le da movimiento y comienza a revestir de carácter e historia a personajes que alli eran meros nombres. Pero sobre todo abre el horizonte social de la novela. La reiteración de los mismos temas presentados con ligeras variaciones, que será una constante en la parte central, aparece ya en este prólogo. «El prólogo tendría así una función de reproducción en miniatura de la estructuración de la novela, sería una estructura en abismo», dice Sobejano ${ }^{67}$, resumiendo las ideas de Anne Marie Vanderlynden. ${ }^{68}$

La parte central de la novela comienza después de que la amiga Valen y el hijo Mario se retiran de la habitación y abarca justamente las cinco horas del velatorio que Carmen insiste en hacer sola, es decir, las Cinco horas con Mario. En esta parte de la novela el tiempo de la narración coincide más o menos con el tiempo de lo narrado. Carmen recorre con su marido muerto otra vez los 23 años de su matrimonio, el noviazgo y también parte de su juventud, es decir más o menos el epacio de tiempo comprendido entre la Guerra Civil y el presente (1966). Como Mario ya no puede responder a su mujer, la disputa que Carmen entiende como diálogo (marcado por «tú dirás», «desengáñate», «¿recuerdas?», «entiéndelo bien», «imagínate», etc.) es aparentemente un monólogo en el que Carmen puede descargar libremente todo lo que le pesa en su alma. Cada capítulo comienza con una cita que Carmen toma de la Biblia de Mario (que está a mano sobre su mesita de noche) de donde lee los pasajes subrayados por él. $Y$ esas citas ponen en marcha su propio discurso. De esta manera Delibes crea la impresión de que es la protagonista quien estructura la novela, puesto que es Carmen quien, al hojear la Biblia, inicia y termina las distintas unidades en que la obra aparece dividida.

Gonzalo Sobejano indica que la relación entre las citas de la Biblia y el discurso puede considerarse un caso claro de «intertextualidad en el sentido más específico del término: un texto (la Biblia) sirve de base a otro (el monólogo). Ahora bien: la Biblia no interesa aquí

${ }^{67}$ Sobejano, Gonzalo: op. cit., $1981^{2}$, p. 28.

68 Vanderlynden, Anne Marie: "Cinco horas con Mario": quelques remarques: une lecture», Les langues néolatines, no. 215, Paris, 1975, pp. 74-93. 
primordialmente como Sagrada Escritura (aunque la profanación que hace la mujer tantas veces es muy significativa), sino como objeto de lectura acotada por Mario, como texto frecuentado y asimilado por él». ${ }^{69}$ Los Neuschäfes ${ }^{70}$ consideran que lo que impulsa el discurso de Carmen es la Biblia que sirve como sustituto de su marido. Entonces el texto sagrado no es un requisito casual, sino la representación póstuma del espíritu de Mario que no está tan callado como en un primer momento pudiera parecer. Porque las citas de la Biblia hablan, en cierto modo, por él e invitan a Carmen para iniciar un discurso cuyo carácter de contestación, defensa y justificación se va haciendo más claro a lo largo de su monólogo. Al mismo tiempo se comprueba que el monólogo es realmente un diálogo y que en el fondo no es ella la que dirige la conversación, sino que solamente reacciona ante el desafío de Mario. Aunque siempre tiene la última palabra, evidentemente es Mario el que tiene la primera; y que su primera palabra influye en las de ella se ve en la cantidad de palabras con las que ella se defiende. Su discurso repite continuamente los mismos motivos con leves variaciones expresivas o de contenido. Como ha afirmado el propio autor: «en la historia de Menchu y Mario hay sucesivos enriquecimientos, pero escasos progresos. Es una historia varada». ${ }^{71}$

Al final del libro se retoma en las últimas 12 páginas la forma narrativa del principio y con ello se cierra el marco. En el epílogo reaparece el joven Mario que entabla una conversación muy seria con su madre en la que intenta explicar a grandes rasgos su idea del futuro a su madre: un futuro más allá del «maniqueísmo» ${ }^{72}$ de sus padres, sin la hipocresía del fariseísmo. «A mí me interesaba particularmente el epílogo para suavizar, con la intervención del hijo, el contenido pesimista de la novela» ${ }^{73}$ explicaba Delibes. El mensaje final está puesto en la boca de un muchacho en quien podemos ver la imagen de la esperanza, de la reconciliación necesaria y del diálogo posible en un futuro democrático, aunque el acuerdo entre las dos generaciones todavía no es posible.

\section{La novela como crítica social}

Si bien es cierto que la protagonista intenta justificar sus hechos ante el cadáver de su marido, no lo es menos que defiende con arrogancia su concepción del mundo, que contrapone a la del marido fallecido. Junto al sentimiento de culpabilidad de Carmen se produce su frustración porque considera que su marido no ha mostrado comprensión hacia sus ideas, su concepto de vida y ni siquiera ha atendido sus más íntimos afanes.

«La novela, ingenua en apariencia, supuso así un toque a jerarquía social, las relaciones entre las clases, el papel de la cultura en la vida de los

\footnotetext{
69 Sobejano, Gonzalo: op. cit., $1981^{2}$, pp. 44-45.

70 Neuschäfes, Mercedes y Hans-Jörg: op. cit., 1985, p. 25.

71 Alonso de los Ríos, César: Conversaciones con Miguel Delibes, Barcelona, Destino, 1993, p. 135.

72 Delibes, Miguel: Cinco horas con Mario, Barcelona, Destino, 198024, p. 290.

De aquí en adelante irán marcadas las páginas citadas de esta edición entre paréntesis, precedidas con las siglas CHM.

73 Alonso de los Rios, César: op. cit., 1993, p. 133.
} 
hombres, las ideologías políticas, la guerra, el patriotismo, los valores espirituales, la educación de los hijos, la condición femenina, la justicia, la castidad, la autoridad, la ley, el orden establecido, la reconciliación de los cristianos o la propia figura de Cristo». ${ }^{74}$

Esta novela planteó en el momento oportuno el problema de la imposible comunicación entre un hombre culto y una mujer de nivel cultural inferior. Como Carmen se encuentra en un estado de gran excitación y como su discurso no escucha ningún testigo vivo, deja exteriorizar sin censura lo que, en otra situación, habrá suavizado o reprimido: la forma de pensar, dominada por la envidia, su posición social, su desprecio por las actividades profesionales de Mario, la profunda desconfianza, agudizada por su limitada cultura, hacia los intelectuales, la fobia política, el odio a los rojos o la creencia en la inmovilidad de las clases sociales como voluntad divina.

La novela es una denuncia por parte de Delibes de todo cuanto creía que necesitaba una revisión. El valor testimonial de la obra en este sentido es indudable porque en ella aparecen reflejados los más variados aspectos del momento histórico en que fue escrita: aspectos sociales, económicos, religiosos y políticos. Delibes ha realizado la radiografia de un régimen y de su historia a través del comportamiento lingüístico de un personaje que es el producto mismo de ese régimen. Pero es sobre todo la forma, elegida en función de la realidad que se quería comunicar, el elemento que indica más allá del mensaje psicológico, el alcance político y social de la obra. La falta de movimiento de una novela en la que no pasa nada, en la que todo se repite casi con las mismas palabras y los personajes no evolucionan, no hace sino reproducir también en su misma estructura circular el estado estático de la España en que se escribió.

\section{Técnicas narrativas}

Tras un minucioso estudio de la novelística delibeana, Alfonso Rey ${ }^{75}$ sostiene que lo más característico del escritor consiste en la novelización del punto de vista de los personajes. Su elemento clave es la capacidad para «poner voces» ${ }^{76}$ en su narración. En el caso de Cinco horas con Mario ha puesto voz a una ama de casa. «En este libro llegué a la conclusión de que Carmen era más consistente y expresaba mejor su elementalidad si tomaba ella la palabra. Dada la mediocridad de esta protagonista, la figura de Mario resultaba, por reflejo, al ser atacada sistemáticemente por la memez, ejemplar para nosotros» ${ }^{77}$ explicaba Delibes. Desde luego, ni Carmen ni Mario hubieran sido posibles en igual intensidad con otra técnica narrativa. La fórmula del sololoquio es la que mejor podía adecuarse al contenido de la novela.

\footnotetext{
${ }^{74}$ Montero, Isaac: «"Cinco horas con Mario": el lenguaje del limbo», Revista de Occidente, núm. 61, Madrid, 1968, p. 112.

75 Rey, Alfonso: op. cit., 1975, pp. 259-282.

76 Ibid., p. 273, nota 44.

77 Alonso de los Ríos, César: op. cit., 1993, p. 132.
} 
Hay muchos términos con los que la crítica ha designado el discurso de Carmen Sotillo ante su marido muerto. Se considera que el uso de técnicas narrativas modernas muchas veces se debe en España en aquellos años al problema de la censura, o sea, en un marco más amplio, a las razones socio-económicas y culturales de posguerra. Un contenido de crítica social como es el texto Cinco horas con Mario, expuesto mediante las técnicas narrativas tradicionales, no hubiera pasado por la censura. Igual como en los casos de Tiempo de silencio y de Señas de identidad, el contenido de la novela de Delibes exige la forma innovadora. Porque en los tres textos sólo por la vía de la técnica se ha podido atacar al contenido, al sistema político y social, y al mismo tiempo esquivar la rígida institución de la censura. En el caso de Cinco horas con Mario hay que hablar de soliloquio de Carmen o mejor dicho, de diálogo sin respuesta con un muerto. El discurso de Carmen tiene todas las características de un diálogo, aunque, al estar su pretendido interlocutor muerto, sólo hay un hablante. Carmen se orienta a su marido muerto para suplicarle, para preguntarle, para dialogar o para confirmar, el "tú" de Carmen en realidad únicamente tiene un destinatario, y es ella misma. Por los tiempos utilizados, especialmente cuando son el futuro y el imperativo, por el tono del lenguaje y por la existencia de preguntas y respuestas, el soliloquio de Carmen puede ser considerado como un diảlogo que tiene un interlocutor ficticio.

Manuel Alvar ${ }^{78}$ considera que en el caso de Cinco horas con Mario el monólogo interior o diálogo interior vienen a ser una misma cosa: se trata del protagonista que habla sin un interlocutor. Que esté muerto o no, no tiene gran importancia, porque no se espera respuesta. Entonces se trata de un diálogo muy especial, porque el personaje se pregunta y se responde con las palabras que necesita en su juego dialéctico, y no con las que podría dar el mudo interlocutor. Darío Villanueva lo califica de «monólogo o monodiálogo plenamente exterions. ${ }^{79}$ Gonzalo Sobejano ${ }^{80}$ también llega a la conclusión de que en la parte central de la novela no hay narrador ni narración, sino un sujeto que habla mentalmente a lo largo de un discurso. Se trata de un discurso monologal (a una sola voz, en primera persona), pero dirigido a una segunda persona, a un tú, como si ésta oyese lo que la primera está diciendo o pensando, y a veces como si fuese capaz de escucharle y responderle. Por eso, no se trata de un monólogo inmanente (en primera persona que se dirige a sí misma, o bien a nadie), sino de un monólogo trascendente de la primera persona a una segunda, como si ésta al menos oyese lo que aquella piensa o dice. Para concluir, se trata de un soliloquio que tiene forma particular, de diálogo (primera persona que se dirige a una segunda), pero diálogo sin respuesta verbal directa por las circunstancias en que se produce. El soliloquio de Carmen es mental que termina por ser verbal cuando el hijo Mario encuentra a su madre de rodillas y le dice en el epílogo: «Me pareció que hablabas sola» (CHM, p. 285).

\footnotetext{
78 Alvar, Manuel: El mundo novelesco de Miguel Delibes, Madrid, Gredos, 1987, pp. 96-101.

79 Villanueva, Dario: «Miguel Delibes de "El camino" (1950) a "Cinco horas con Mario" (1966)» en Estructura y tiempo reducido en la novela, Valencia, Bello, 1977, pp. 238-247.

80 Sobejano, Gonzalo: op. cit., $1981^{2}$, p. 24.
} 
Cuando le preguntaron a Delibes sobre las innovaciones técnicas de Cinco horas con Mario, pensaba que podía considerarse como una cierta novedad la técnica de los círculos concéntricos:

«En Cinco horas con Mario sí puede considerarse una cierta novedad esa especie de fórmula de círculos concéntricos que he empleado. Quiero decir que los personajes y el tema de la novela están ya prácticamente definidos en los primeros capítulos. En los siguientes, el núcleo central se va ampliando, como cuando tiras una piedra al río, en círculos cada vez más grandes, con nuevas anécdotas, sugerencias y matices. La historia, pues, apenas progresa, simplemente se enriquece». ${ }^{81}$

Si el problema de la incomprensión es el principal en las tres secciones de la novela (prólogo, monólogo, epílogo), los cambios en el número de círculos y en el estilo del discurso demuestran que la imagen concéntrica, centrada siempre en Carmen, se asocia con una sola perspectiva que de por sí es circular. La imagen de círculos concéntricos sirve para describir un texto que proyecta globalmente la misma figura que vuelve a aparecer en cada sección textual.

La repetición es fundamental para la técnica de la novela y contribuye a la fluidez de la prosa mientras subraya la función mimética del discurso narrativo. Gérard Genette ${ }^{82}$ establece entre la repetición de los acontecimientos narrados (de la historia) y de los enunciados narrativos (del relato) un sistema de realciones que a priori puede reducirse a cuatro tipos: acontecimiento repetido o no, enunciado repetido o no. Un relato puede contar una vez lo que ha ocurrido una vez, $n$ veces lo que ha ocurrido $n$ veces, $n$ veces lo que ha ocurrido una vez, una vez lo que ha ocurrido $n$ veces. En Cinco horas con Mario hay un sólo personaje quien cuenta o rememora $n$ veces las mismas cosas y no distintos personajes los que aportan cada uno su versión. Sin embargo, dentro de la perspectiva dominante de Carmen, asoman a veces otros puntos de vista. $\mathrm{Y}$ justamente gracias a esta técnica reiterativa, Delibes puede incluir en el soliloquio de la protagonista otros relatos auténticos que el lector debe ir reconstruyendo y que sirven de soporte a la parte central. A medida que va transcurriendo la novela, el núcleo de estos relatos se va enriqueciendo con nuevos detalles, de manera que sólo al final el lector puede tener una visión final.

Además de su valor de un documento social de una época, Cinco horas con Mario es un espléndido experimento lingüístico del lenguaje hablado. Para Agnes Gullón la invención más llamativa del libro y quizá la razón principal de su éxito está en «la creación de un habla que por su sostenida energía mimética parece una recreación del lenguaje real de un tiempo y un grupo social y de un personaje-persona muy representativo». ${ }^{83} \mathrm{El}$ lenguaje de Carmen es el de una mujer de clase media. Y la adecuación entre lo que dice y su forma de decirlo

\footnotetext{
81 Alonso de los Ríos, César: op. cit., 1993, p. 131.

82 Genette, Gérard: op. cit., 1989, p. 173.

83 Gullón, Agnes: La novela experimental de Miguel Delibes, Madrid, Taurus, 1980, pp. 57-58.
} 
es perfecta. Ella se expresa en un lenguaje coloquial, lleno de repeticiones, formas enfáticas, modismos, muletillas, imprecisiones, frases sin terminar, construcciones elípticas, en breve, toda la gama de formas lingüísticas que constituyen el habla común y conversacional. En su discurso llama la atención el empleo incesante de vocativos, dirigidos a Mario como destinatario de un mensaje, que van desde lo afectivo hasta lo agresivo. También utiliza mucho frases hechas y refranes que expresan su mentalidad y su origen, la burguesía mediana provinciana. Para Carmen, el mundo está bien hecho, todo funciona dentro de un orden que no merece la pena cambiar, porque si las cosas han sido siempre así, en el futuro tampoco tienen que cambiar. Por eso prefiere en su habla las expresiones conocidas y locuciones fijas.

Los versículos bíblicos que Mario ha subrayado en su Biblia y que encabezan cada capítulo del soliloquio son la voz del marido muerto que se explica, defiende sus ideales y principios y procura póstumamente instruir a su mujer. Las citas bíblicas son el medio por el cual Carmen habla al cadáver de su marido, que lo mismo que cuando vivía no puede escucharla. Sin embargo, el hecho de que está físicamente muerto no le impide a Mario que no le conteste. A lo largo de su discurso, Carmen lee las citas bíblicas, las interpreta dentro del contexto de su vida, a veces fuera del contexto bíblico, y las toma como punto de arranque para dirigirse a su marido. En su totalidad, las citas componen un resumen de la ideología de Mario que contrasta con las ideas de su mujer. Todas aluden a asuntos o aspectos de la vida sobre los que Mario y Carmen no están de acuerdo. Sirven para resaltar el retrato del marido muerto como una figura trágica que, luchando por el bien en un ambiente hostil y sin apoyo de su esposa, se siente frustrado.

El fin de Cinco horas con Mario es dibujar caracteres opuestos, personajes concretos que representan y definen en términos trascendentes la problemática del pueblo español en la época de posguerra. Además del comentario social, la novela representa una sobresaliente obra de arte. Los mismos rasgos de contraste que retratan a los protagonistas se repiten en todos los elementos estructurales de la obra. El contenido se desuelve en dos planos temporales, el pasado y el presente, y en dos espacios, el interior cognitivo y el de la realidad exterior. El monólogo que parece ser un diálogo particular en que ambos protagonistas exponen respectivamente sus puntos de vista contrarios. Escondido detrás de la pareja, Miguel Delibes revela un problema nacional de la España de posguerra y una propuesta para solucionar el humanismo y el amor cristiano.

\section{Conclusiones}

La novela española de posguerra se desarrolla en etapas que aproximadamente coinciden con las décadas, los años cuarenta, cincuenta, sesenta cuando se producen unos cambios significantes en el campo narrativo que puede llamarse novela de ruptura. La fecha clave es el año 1962 cuando se publica Tiempo de silencio de Luis Martín-Santos. Además, esta fecha coincide, más o menos, con el momento de despegue hacia el desarrollo económico de la 
sociedad española y la desaparición paulatina del sistema de censura. Esto produce un cambio de mentalidad en el novelista:

«... en las primeras fases del despegue, el novelista se siente obligado a presentar hechos y realidades que no encuentran cabida en la información o en el reportaje. A medida que el deasrrollo se realiza, el tema que se plantea al novelista no es la denuncia de hechos, sino intentar aprehender el sentido global de la sociedad». ${ }^{84}$

Es justamente el momento de tránsito entre la novela testimonial, característica esencial del neorrealismo, y lo que llamamos novela dialéctica o novela de ruptura, que define perfectamente la etapa en los años sesenta. Siguendo este criterio, no es difícil señalar cómo después de la obra de Martín-Santos Cinco horas con Mario y Señas de identidad son hitos importantes del realismo dialéctico. El novelista español de esta etapa pierde interés por el hecho concreto, por la historia, por lo que llamamos anécdota de la novela, para intentar captar el sentido global de la sociedad en la que vive. La naturaleza conflictiva de esta sociedad se refleja en la estructura de la novela. Se establece un diálogo entre el novelista y el mundo que le rodea, y este diálogo es su novela. El novelista neorrealista no dialogaba con su mundo porque las palabras que empleaba formaban parte de ese mundo. La novela diálectica nace cuando el novelista decide rechazar las voces prestadas y descubre su propia voz, que le va a servir no ya para descubrir, sino para dialogar con el mundo que lo consiguen mediante la destrucción de lo tradicional: «En el vasto y sobrecargado almacén de antigüedades de nuestra lengua sólo podemos crear destruyendo: una destrucción que sea a la vez creación; una creación a la par destructiva». ${ }^{85}$ Primero Martín-Santos y luego Goytisolo y Delibes consideraban que únicamente de este modo podrían reaccionar de una manera artísticamente sensible a las condiciones agobiantes de su época.

La novela dialéctica supone un cambio radical en la parte formal del texto, en las técnicas narrativas y en el lenguaje, pero siempre de acuerdo con el contenido, porque al fin y al cabo su fin era transponer sensiblemente la condición social de su momento contemporáneo, igual como el del realismo social, pero mediante otras técnicas narrativas que las del realismo objetivo. Delibes ${ }^{86}$ considera que el núcleo de cada novela debe ser la vida y que lo primordial en una novela es el qué se dice, y sólo después el cómo se dice. El realismo dialéctico no se aleja del plano real, sin embargo, la técnica, el estilo, la elaboración no concuerdan con el realismo objetivo, al que más bien se oponen. La existencia se presenta como el resultado de un conglomerado de hechos que van encandenándose unos a otros con los comentarios sutiles del autor. Diversos planos, exteriores e interiores, ocurren simultáneamente, y de ahí que al lado del diálogo abunde la introspección, el monólogo. El texto pasa de la novela dialogada a la novela discursiva.

\footnotetext{
${ }^{84}$ Morán, Fernando: op. cit., 1971, p. 113.

85 Goytisolo, Juan: op. cit., $1982^{2}$, p. 93.

86 Delibes, Miguel: La censura de prensa en los años 40 y otros ensayos, Valladolid, Ámbito Ediciones, 1985.
} 
Por encima de las características personales de cada autor, de sus peculiaridades de estilo y de sus preferencias temáticas, es posible advertir algunos rasgos comunes en las tres obras tratadas de los años sesenta. España está presente en todas como preocupación esencial o trasfondo que sirve de base a toda la narración. La huella de la Guerra Civil se manifiesta, directa o indirectamente, en el desarrollo de las fábulas. El ambiente cultural de la posguerra se hace patente a través de las situaciones y el desarrollo de los hechos. El propósito de desmitificar la vida española y poner al desnudo sus prejuicios, convencionalismos y falsas creencias, con deseo de crear una nueva actitud ante la cambiante realidad histórica es también común en todas.

Además del fondo temático de España, hay otros temas comunes que es posible destacarlos. El catolicismo como religión determinante del pueblo español y la Iglesia como fuerza social predominante, son vistos como responsables de muchos de los errores y limitaciones de la vida española. Las características de la sociedad española que se está cambiando en la de consumo se presentan con angustia existencial, con la preocupación de que el hombre, dominado por lo material, se olvide de lo ontológico. Este problema se agudiza en España por la falta de libertad política y por el rápido cambio de sociedad subdesarrollada a sociedad industrial sin la correspondiente evolución de los principios morales, políticos y culturales que deberían acompañar una transformación social.

Las tres obras parten de la realidad, de hechos concretos y vitales, que tratan de penetrarlos y trascenderlos, en la seguridad de que hay siempre algo más allá de lo visible, de lo tangible. La narrativa española deja atrás la estrechez documental y la limitadora fidelidad a los hechos palpables, para abrirse a una perspectiva de totalidad, a una realidad que abarque lo vivo y lo soñado, lo consciente y lo inconsciente, lo inmanente y lo trascendente. El lector de repente se encuentra ante una realidad dialéctica, distorsionada y multiplicada en diversos planos de tiempo y de espacio.

Los personajes en las tres obras no son considerados como una abstracción idealizada sino como seres vivos con los pies en la tierra, sujetos a debilidades y miserias físicas y morales, que obran bien o mal, que poseen vicios y virtudes, lo que elimina la vieja dicotomía moral entre buenos y malos. Queda evidente, asimismo, la incomunicación del ser humano, su incapacidad de llegar a comprender a los demás y a ser comprendido por ellos. Esa subjetividad se manifiesta también en la técnica, con el uso de diferentes puntos de vista para presentar los mismos hechos. El propósito de tal técnica es relativizar la verdad oficial de la existencia humana, aparente y falsamente unánime. Cierto es que cada hombre posee una sola dimensión de la verdad, para él absoluta, pero relativa en términos de la realidad última. En este aspecto filosófico hay una evidente preocupación por el tiempo, que se manifiesta desde los títulos mismos de las obras: Tiempo de silencio, Cinco horas con Mario; Señas de identidad empieza con una invocación de Quevedo: «Ayer se fue; Mañana no ha llegado» (SI, p. 9).

Los relatos de las tres novelas por sí mismos no cuentan gran cosa, en las tres podemos decir que no pasa nada. Los personajes no experimentan evolución alguna; los portavoces de 
la liberalización, de la nueva ideología son individuos específicos, intelectuales cuya habla queda muda, en silencio o sin eco, es decir, no la comprenden. Sin embargo no se dejan ahogar completamente por las circunstancias en que viven porque su esperanza es la reconciliación nacional, aunque utópica en aquel momento. El monólogo de la España tradicional en las tres novelas ante el silencio implacable de otra España que se afanaba por abrir nuevos horizontes, encarna un estado de realidad de los años sesenta. La España de la Victoria estaba derrumbándose. Como Carmen Sotillo que empieza con grandes palabras arrojándolas sin piedad a su víctima y termina suplicándole de rodillas una sola palabra.

Vistas desde la compleja relación, aquí estudiada, texto narrativo - sociedad, podemos concluir que Tiempo de silencio, Señas de identidad y Cinco horas con Mario son ejemplos de un nuevo paradigma, llamado realismo dialéctico, o sea, que pueden ser determinadas como novelas de ruptura o novelas dialécticas.

\section{BIBLIOGRAFIA SELECTA}

ABelláN, José Luis: La cultura en España. Ensayo para un diagnóstico, Madrid, Cuadernos para el Diálogo, 1971.

ABELLÁN, Manuel L.: Censura y creación literaria en España (1939-1976), Barcelona, Península Ediciones, 1980.

Alonso de los Ríos, César: Conversaciones con Miguel Delibes, Barcelona, Destino, 1993. ALVAR, Manuel: El mundo novelesco de Miguel Delibes, Madrid, Gredos, 1987.

ANÓNIMO: «Baroja declara que no es tiempo de novelas», El Español, núm. 10, Madrid, 2 de enero de 1943.

BORGES, Jorge Luis: La poesia gauchesca, Buenos Aires, Discusión, 1957.

BUCKLEY, Ramón: "Tiempo de silencio" de Luis Martín-Santos, Madrid, Alborada, 1988.

BUCKLEY, Ramón: Problemas formales en la novela española contemporánea, Barcelona, Península, $1973^{2}$.

CARPEnTIER, Alejo: Tientos y diferencias, Barcelona, Plaza \& Janés Editores, 1987.

CASTRO, Américo: La realidad histórica de España, México, Porrúa, 1971.

CELA, Camilo José: «Dos tendencias de la nueva literatura española», Papeles de Son Armadans, núm. LXXIX, Madrid - Palma de Mallorca, 1962.

CELA, Camilo José: «Encuesta sobre la invención literaria», La Estafeta Literaria, núm. 28, Madrid, 10 de junio de 1945.

ClOTAS, Salvador: Prólogo a "Apólogos y otras prosas inéditas" de Luis Martín-Santos, Barcelona, Seix Barral, 1970.

CORREA, Pedro: «Narrativa española actual», Nuestro Tiempo, núm. 225, Madrid, marzo de 1973.

CURUTCHET, Juan Carlos: «A partir de Luis Martín-Santos» en Cuatro ensayos sobre la nueva novela española, Montevideo, Editorial Alfa, 1973.

Delibes, Miguel: Cinco horas con Mario, Barcelona, Destino, $1980^{24}$. 
DELIBES, Miguel: La censura de prensa en los años 40 y otros ensayos, Valladolid, Ámbito Ediciones, 1985.

DíAZ, Elías: Pensamiento español contemporáneo, 1939-1975, Madrid, Edicusa, $1978^{2}$.

DoBlado, Gloria: España en tres novelas de Juan Goytisolo, Madrid, Nova Scholar, 1988. DOMENECH, Ricardo: «Ante una novela irrepetible», Ínsula, núm. 187, Madrid, junio de 1962. DUQUE, Aquilino: «Realismo pueblerino y realismo suburbano. Un buen entendedor de la realidad: Luis Martín-Santos», Indice, núm. 185, Madrid, junio de 1964.

FUENTES, Carlos: La nueva novela hispanoamericana, México, Cuadernos de Joaquín Mortiz, 1969.

GENETTE, Gérard: Figuras III, Barcelona, Lumen, 1989.

GIL CASADO, Pablo: La novela social española (1920-1971), Barcelona, Seix Barral, $1973^{2}$. Gould Levine, Linda: Juan Goytisolo: la destrucción creadora, México, Juan Mortiz, 1976. GoÑI, Javier: Cinco horas con Miguel Delibes, Madrid, Anjana Ediciones, 1985.

Goytisolo, Juan: "Los escritores españoles frente al toro de la censura» en El furgón de cola, Barcelona, Seix Barral, $1982^{2}$.

Goytisolo, Juan: Problemas de la novela, Barcelona, Seix Barral, 1959.

Goytısolo, Juan: Señas de identidad, Madrid, Narrativa Mondadori, 1991.

Gullón, Agnes: La novela experimental de Miguel Delibes, Madrid, Taurus, 1980.

KRISTEVA, Julia: El texto de la novela, Barcelona, Editorial Lumen, $1981^{2}$.

MAIner, José Carlos: Prólogo a "Tiempo de destrucción"de Luis Martín-Santos, Barcelona, Seix Barral, 1975.

Martínez CACHERo, José María: La novela española entre 1936 y 1969. Historia de una aventura, Madrid, Castalia, 1973.

MARTínez CACHERo, José María: La novela española entre 1936 y 1980 . Historia de una aventura, Madrid, Editorial Castalia, 1985.

Martín-SAnToS, Luis: «Baroja - Unamuno», en Sobre la generación del 98. Homenaje a don Pepe Villar, San Sebastián, 1963.

MARTÍN-SANTOS, Luis: Tiempo de destrucción, Barcelona, Seix Barral, $1983^{2}$.

Martín-Santos, Luis: Tiempo de silencio, Barcelona, Seix Barral, $1989^{31}$.

MATUTE, Ana María: «A Wounded Generation», The Nation, Londres, noviembre de 1965. MedinA-Bocos, Amparo: Delibes Miguel (1920- ), "Cinco horas con Mario", Madrid, Alhambra, 1987.

MONTERO, Isaac: "Cinco horas con Mario": el lenguaje del limbo», Revista de Occidente, núm. 61, Madrid, 1968.

MORÁN, Fernando: «Sobre el semidesarrollo», separata del Boletín informativo de ciencia política, núm. 4, Madrid, junio de 1970.

MORÁN, Fernando: La destrucción del lenguaje y otros ensayos literarios, Madrid, Editorial Mezquita, 1982.

MORÁn, Fernando: Novela y semidesarrollo, Madrid, Taurus, 1971. 
NeUSCHÄFES, Mercedes y Hans-Jörg: "“Cinco horas con Mario", veinte años después y desde fuera», Los Cuadernos del Norte, núm. 34, Oviedo, 1985.

ORTEGA, José: «Realismo dialéctico de Martín-Santos en "Tiempo de silencio"», Revista de Estudios Hispánicos, núm. 1, University of Alabama, U.S.A., 1969, pp. 1-10.

PAUK, Edgar: Miguel Delibes: desarrollo de un escritor (1947-1974), Madrid, Gredos, 1975.

PRINCE, Géralde: «Introduction à l'étude du narrataire», Poétique, núm. 14, 1974.

REY, Alfonso: Construcción y sentido de "Tiempo de silencio", Madrid, José Porrúa Turanzas, $1980^{2}$.

REY, Alfonso: La originalidad novelística de Delibes, Santiago de Compostela, Universidad de Santiago de Compostela, 1975.

RIDRUEJO, Dionisio: «La vida intelectual española en el primer decenio de la posguerra», Triunfo, no. 507, Madrid, 17 de junio de 1972.

ROBERTs, Gemma: Temas existenciales en la novela española de postguerra, Madrid, Gredos, $1978^{2}$.

RODRíGuez MONEGAL, Emir: El arte de narrar, Caracas, Venezuela, Monte Avila Editores, $1977^{2}$.

SANTANA, Lázaro: «La vida y la brújula. Conversación con Borges», Ínsula, núm. 258, Madrid, mayo de 1968.

SANZ Villanueva, Santos: Tendencias de la novela española actual, Madrid, Edicusa, 1972.

SOBEJANO, Gonzalo: «Direcciones de la novela española de posguerra», Boletín de la Asociación europea de profesores de español, núm. 6, Madrid, 1972.

SOBEJANO, Gonzalo: Estudio introductorio a "Cinco horas con Mario"- versión teatral, Madrid, Espasa Calpe, $1981^{2}$.

VANDERLYNDEN, Anne Marie: «"Cinco horas con Mario": quelques remarques: une lecture», Les langues néolatines, no. 215, Paris, 1975.

VillanueVA, Darío: «Miguel Delibes de "El camino" (1950) a "Cinco horas con Mario" (1966)» en Estructura y tiempo reducido en la novela, Valencia, Bello, 1977.

WINECOFF DÍAZ, Janet: «Luis Martín-Santos and the Contemporary Spanish Novel», Hispania, núm. LI, University of Massachusetts, U.S.A.

YNDURÁIN, Francisco: «La novela desde la segunda persona» en Gullón, Agnes y Germán: Teoría de la novela (Aproximaciones hispánicas), Madrid, Taurus, 1974. 


\section{PRIPOVEDNE TEHNIKE V POVOJNEM ŠPANSKEM ROMANU S POSEBNIM POUDARKOM NA ŠESTDESETA LETA DVAJSETEGA STOLETJA}

Doktorska disertacija obravnava pripovedne tehnike $v$ španskem romanu po državljanski vojni s posebnim poudarkom na šestdeseta leta oziroma na tri romane, ki predstavljajo prelomnico v povojnem španskem pripovedništvu. Gre za romane Čas tišine (Tiempo de silencio, 1962) Luisa Martína-Santosa, Znaki identitete (Señas de identidad, 1966) Juana Goytisola in Pet ur z Mariem (Cinco horas con Mario, 1966) Miguela Delibesa.

Vsi trije romani po svoje, ceprav med seboj podobno, predstavljajo na socialni ravni pretanjeno kritiko povojnega režima, ki je omejeval človekovo svobodo bivanja in ustvarjanja. Šele $v$ šestdesetih letih se $\mathrm{v}$ Španiji obdobje totalitarizma začenja počasi tajati, saj zapihajo prvi vetrovi sramežljive demokracije, svobode in upanja. Takšna družbena realnost se zrcali $\mathrm{v}$ omenjenih romanih ne toliko $\mathrm{v}$ tematiki kolikor $\mathrm{v}$ notranji romaneskni strukturi, predvsem pri uporabi specifičnih pripovednih tehnik, drugačne karakterizacije junakov in novega pripovednega diskurza.

C̆as tišine je prvi roman, ki uvaja dialektični realizem kot novo literarno usmeritev v povojnem španskem pripovedništvu. Ta sicer še vedno ohranja tesne vezi, predvsem tematske, s predhodno strujo, s socialnim ali objektivnim realizmom, vendar pa predvsem na formalnem področju uvaja vrsto novosti, kot so notranji monolog, menjavanje pripovednih perspektiv, medbesedilnost, uporabo pogovornega jezika, neologizmov, posameznih besed ali celih stavkov $v$ tujih jezikih in podobno. Čeprav se na prvi pogled zdi, da gre zgolj za nekakšne zunanje spremembe, je osnovni namen formalnih novosti $v$ tesni povezavi s sporočilom pripovednega besedila, ki je usmerjeno $\mathrm{v}$ posmehljivo razkrivanje španske tradicije. 